$1-2009$

\title{
Symbol or Substance: An Empirical Assessment of State Responses to Kelo
}

Andrew P. Morriss

Texas A\&M University School of Law, amorriss@law.tamu.edu

Follow this and additional works at: https://scholarship.law.tamu.edu/facscholar

Part of the Law Commons

\section{Recommended Citation}

Andrew P. Morriss, Symbol or Substance: An Empirical Assessment of State Responses to Kelo, 17 Sup. Ct. Econ. Rev. 237 (2009).

Available at: https://scholarship.law.tamu.edu/facscholar/249

This Article is brought to you for free and open access by Texas A\&M Law Scholarship. It has been accepted for inclusion in Faculty Scholarship by an authorized administrator of Texas A\&M Law Scholarship. For more information, please contact aretteen@law.tamu.edu. 


\title{
Symbol or Substance? An Empirical Assessment of State Responses to Kelo
}

\author{
Andrew P. Morriss*
}

The Kelo decision provoked considerable legislative activity as 46 states adopted legislation on eminent domain in its aftermath. Only about half adopted restrictions that were more than symbolic, however. This paper examines those responses using a logistic regression analysis and finds that all else equal: (1) states where legislatures were more constrained by tax and expenditure limits were less likely to adopt substantive restrictions; (2) a larger number of Republicans in the state legislature made a state more likely to adopt a substantive restriction; (3) overall Republican strength (as measured by gubinatorial elections) made states less likely to adopt a substantive response, suggesting political competitiveness not ideology motivated action; (4) there was no evidence that measures of an electorate's overall ideology (with respect to environmental, liberal, or conservative causes) made a difference; (5) economically growing states were more likely to adopt substantive restrictions; and (6) greater degrees of inequality and larger African-American populations were not correlated with the type of response. Taken together, these results suggest a public choice model of

* H. Ross \& Helen Workman Professor of Law \& Professor of Business Administration, University of Illinois; Senior Scholar at the Mercatus Center at George Mason University, and Senior Fellow, Property \& Environment Research Center, Bozeman, Montana. A.B. Princeton University; J.D., M.Pub.Aff., University of Texas; Ph.D. (Economics) Massachusetts Institute of Technology. Thanks to Jonathan Adler, William Bogart, Michael Heise, Randall Holcombe, Robert Lawless, Ilya Somin, Tom Ulen, participants at the Southern Economic Association 2007 conference session on "Takings as Government Failure," and participants at the Takings symposium at the University of California Santa Barbara in May 2006 for comments on earlier versions. 
legislative action, rather than an ideological one, with legislatures facing other constraints (e.g. TEL and slower growth) being less likely to give up valuable eminent domain powers and legislatures where adoption of real reform was less costly (faster growth) or more beneficial (more competitive political environments) more likely to do so.

\section{INTRODUCTION}

The Supreme Court's decision in Kelo v. City of New London drew more attention than other recent court opinions: ${ }^{1}$ Professor Thomas Merrill termed it "unique in the modern annals of law" for the overwhelming negative response, ${ }^{2}$ while others noted that Kelo "fanned into a flame" property rights rhetoric; ${ }^{3}$ set off "a firestorm of popular outrage;" ${ }^{\prime \prime}$ was "profoundly disquieting, ${ }^{\prime 5}$ and was one of the most "riveting" Supreme Court decisions of the past fifty years. ${ }^{6}$ In addition to attracting critical commentary in the press, somewhat more mixed scholarly commentary, ${ }^{7}$ and overwhelmingly critical discussion in alternative media and online, ${ }^{8}$ Kelo caught the attention of state legislators. Indeed the majority opinion in Kelo upholding the use of eminent domain for economic development invited legislators' attention, with Justice Stevens stressing the safeguards pro-

\footnotetext{
${ }^{1}$ Janice Nadler, Shari Seidman Diamond and Matthew M. Patton, Government Takings of Private Property: Kelo and the Perfect Storm in Public Opinion and Constitutional Controversy * 294 (Nathaniel Persily, Jack Citrin and Patrick Egan) (forthcoming 2008), Table 12.2 (comparing Kelo and other Supreme Court opinions in terms of press coverage).

${ }^{2}$ Thomas W. Merrill, Six Myths About Kelo, 20 Prob \& Prop 19, 19 (2006).

${ }^{3}$ Marcilynn A. Burke, Much Ado About Nothing: Kelo v City of New London, Sweet Home v Babbitt, and Other Tales from the Supreme Court, SSRN at [2].

${ }^{4}$ Nicole Stelle Garnett, The Neglected Political Economy of Eminent Domain, 105 Mich L Rev 101, 103 (2006). See also James W. Ely, Jr, Kelo: A Setback for Property Owners, 20 Prob \& Prop 14, 14 (2006) (also terming reaction "a firestorm").

${ }^{5}$ Ely, 20 Prob \& Prop at 14 (cited in note 4).

${ }^{6}$ Richard A. Epstein, Kelo: An American Original, 8 Green Bag 2d 355, 355 (2005).

${ }^{7}$ Property rights proponents such as Richard Epstein found it "ill-considered," Richard A. Epstein, The Public Use, The Public Trust, $\Theta$ Public Benefit, 9 Green Bag $2 \mathrm{~d} 125,125$ (2006), while academic defenders such as Thomas Merrill argued that Kelo represented nothing new. See Merrill, 20 Prob \& Prop at 19 (cited in note 2).

${ }^{8}$ See, example, Scott Johnson, Takings: An Introduction, Powerline (June 23, 2005), online at http://www.powerlineblog.com/archives/010822.php (leading conservative blog concluding that "The jurisprudence represents the Court's accommodation of government power over individual rights."); Russell Mokhiber and Robert Weissmann, Focus on the Corporation, Eat the State! (July 6, 2005), online at http://eatthestate .org/09-22/FocusOnCorporation.htm (leftist authors argued that "eminent domain in economic development cases is a tool that, as an empirical matter, facilitates benefits only for the rich and powerful. It is a tool that should be checked.").
} 
vided by the political process, ${ }^{9}$ noting the inadequacy of the judiciary to review the use of eminent domain, ${ }^{10}$ and refusing to be drawn into a debate over the merits of the use for which the property was being taken, ${ }^{11}$ while "emphasiz[ing] that nothing in our opinion precludes any State from placing further restrictions on its exercise of the takings power. ${ }^{\prime 12}$ In the two years after the June 23, 2005 decision, legislation to restrict eminent domain powers was introduced in forty-

9 The majority stressed the extensive process undertaken by the New London Development Corporation ("NLDC") and the extensive review of those plans by various state agencies and city bodies. The planning process was approved by the city council, neighborhood meetings were held "to educate the public about the process," an "integrated development plan" was prepared by the NLDC, and "various state agencies studied the project's economic, environmental, and social ramifications" using "a team of consultants" to evaluate "six alternative development proposals for the area, which varied in extensiveness and emphasis." Kelo, 125 S Ct 2655, 2659 \& n 2. The existence of "a 'carefully considered' development plan" and lack of "evidence of an illegitimate purpose" took the Kelo facts out of the forbidden category of takings aimed at simply transferring benefits from one owner to another, based on a "mere pretext." Kelo, 125 S Ct 2655, 2662. The lack of "a particular class of identifiable individuals" who benefited from the plan was further evidence that the development plan had a public purpose.

${ }^{10}$ The majority thought courts incapable of evaluating the "diverse and always evolving needs of society" that might motivate the use of eminent domain powers. Kelo, 125 S Ct 2655,2662 . Quoting extensively from a particularly vapid 1954 opinion by Justice William $O$. Douglas, the majority noted that " $t$ the concept of public welfare is broad and inclusive.... The values it represents are spiritual as well as physical, aesthetic as well as monetary. It is within the power of the legislature to determine that the community should be beautiful as well as healthy, spacious as well as clean, well-balanced as well as carefully patrolled." Kelo, $125 \mathrm{~S} \mathrm{Ct} 2655,2662$. Moreover, "the needs of society have evolved over time in response to changed circumstances." Kelo, $125 \mathrm{~S} \mathrm{Ct} 2655$, 2663. Faced with this broad array of potential community values, the Kelo majority held that "empirical debates over the wisdom of takings-no less than debates over the wisdom of other kinds of socioeconomic legislation-are not to be carried out in the federal courts." Kelo, $125 \mathrm{~S} \mathrm{Ct} \mathrm{2655,2667.} \mathrm{The} \mathrm{question} \mathrm{was} \mathrm{thus}$ whether New London's plan fell within the "broad and inclusive" boundaries of permissible public purposes, a question that has only one realistic answer outside of the most blatant examples of rent-seeking. (Justice Thomas's dissent terms this "affording almost insurmountable deference to legislative conclusions that a use serves a 'public use.'" Kelo, 125 S Ct 2655, 2684 (Thomas, J., dissenting).| Legislatures, not courts, were the proper forums to debate the merits of advantaging one type of property use over another.

"The majority refused to review the details of the development plan, such as the inclusion of the individual properties within the development plan, again holding that the courts lacked the capacity to review such determinations. Kelo, 125 S Ct 2655, 2668. Again quoting Justice Douglas's opinion in Berman, the majority concluded that "[o]nce the question of the public purpose has been decided, the amount and character of the land to be taken for the project and the need for a particular tract to complete the

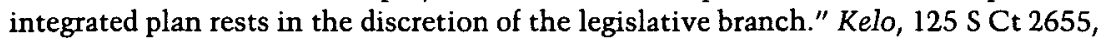
2668, quoting Berman, 348 US at 35-36.

${ }^{12}$ Kelo, 125 S Ct 2655, 2669. 
six states, with multiple bills in many states, and forty-two states enacted legislation or constitutional amendments restricting the use of eminent domain.

However, all legislative responses to Kelo were not equal. Some states adopted symbolic legislation, making no significant change in the substantive constraints on the exercise of eminent domain powers by the state or local governments. For example, while Connecticut amended its statutes to require a two-thirds vote of the government body proposing to take the property, give former owners rights of first refusal to buy back properties if the projects for which the properties were taken fell through, and restrict the use of eminent domain for the "primary purpose" of increasing local tax revenue, ${ }^{13}$ these changes did not pose a significant obstacle to the exercise of eminent domain powers..$^{14}$ Indeed, in my judgment the taking at issue in Kelo would have not been prevented by any of these three changes. ${ }^{15}$ However, some states adopted substantive changes that did reduce the ability of state and local governments to use their eminent domain powers. For example, Florida adopted legislation that effectively forbade local governments' use of eminent domain to eliminate blight and required municipalities to wait ten years before transferring any property acquired through eminent domain to a private owner ${ }^{16}$ as well as a state constitutional amendment that required a three-fifths major-

13 "An Act Revising The Process For The Taking Of Real Property By Municipalities For Redevelopment And Economic Development And Revising The Process For Providing Relocation Assistance For Outdoor Advertising Structures Acquired By The Commissioner Of Transportation," 2007 Conn Legis Serv PA 07-141 (SSB 167).

${ }^{14}$ Castle Coalition, 50 State Report Card: Tracking Eminent Domain Reform Legislation since Kelo 11 (August 2007) online at http://www.castlecoalition.org/pdf/ publications/report_card/50_State_Report.pdf ["Unfortunately, SB 167 [the Connecticut reform legislation] offers no substantive property rights protection .... Without stronger eminent domain reform, Connecticut continues to have some of the most broad and easily abused eminent domain laws in the nation.").

${ }^{15}$ The first refusal provisions would have been irrelevant, since Kelo involved the initial taking, not the collapse of a project and distribution of the land. The limit on takings with the "primary purpose" of increasing local tax revenue would have been irrelevant as the Supreme Court majority accepted New London's claim that the development plan was "projected to create in excess of 1,000 jobs, to increase tax and other revenues, and to revitalize an economically distressed city, including its downtown and waterfront areas." $125 \mathrm{~S} \mathrm{Ct}$ at 2658 . Finally, the $2 / 3$ rds vote requirement, although not satisfied in Kelo because it did not apply at the time, likely would not have presented a problem, as the development plan was not the subject of any significant opposition from any New London officeholder. Moreover, the New London City Council voted 5-2 to evict the Kelo plaintiffs after its victory in the Supreme Court, some evidence that the initial plan would have had similar support. Elizabeth Mehren, New London Council Votes to Oust Eminent Domain Holdouts, LA Times (June 7, 2006).

${ }^{16}$ An act relating to eminent domain, 2006 Fla Sess Law Serv Ch 2006-11 (HB 1567). 
ity vote in both houses of the state legislature to grant exemptions from these requirements. ${ }^{17}$ Why the difference? Why did some states adopt meaningful reforms of eminent domain while others did not?

One possibility is that some states are simply more protective of property rights than other states. Perhaps Texas, with its long history of private property, ${ }_{1}^{18}$ was simply more likely than Florida, with its more transient population and state-wide land use planning, to protect its citizens' homes from eminent domain abuse for cultural reasons. Yet Texas scored a $\mathrm{C}$ - while Florida received an $\mathrm{A}$ on the Castle Coalition's "Report Card" on eminent domain reform. ${ }^{19}$ Any such link was thus more subtle than such crude stereotypes. And the correlation between real, substantive reform of eminent domain and legislative responses to protect property rights from regulatory takings was not particularly high: only 12 of 23 states adopting one of those earlier reforms adopted substantive eminent domain reforms in the two years after Kelo, while nine of the 27 not adopting one of the earlier reforms adopted an eminent domain reform after Kelo. Thus only $60 \%$ of the states' records on the two sets of property rights protections matched up, a Pearson correlation coefficient of just 0.19 , well below the level for statistical significance. See Table 1.

To explain why states differed in their responses, I focus on the costs and benefits of restrictions on the use of eminent domain for those voting on the reforms: legislators. Three aspects are most important. First, although Kelo revealed that eminent domain was unpopular with the public at large, ${ }^{20}$ there remained an important constituency that supports its use: government officials. Its supporters see eminent domain as a "vital economic development tool" state and local governments, allowing important redevelopment projects to take place and potentially saving local communities from economic decline or worse. ${ }^{22}$ To its opponents, eminent domain is a

${ }^{17}$ Fla Const Art X, sec 6/c).

${ }^{18}$ See Andrew P. Morriss, Returning Justice to Its Private Roots, $68 \mathrm{U}$ Chi L Rev $551,567-70$ (2001) (describing role of private property rights in development of Texas land use).

${ }^{19}$ The report card and the organization are described in more detail below. See notes 41-44 and associated text.

${ }^{20}$ Nadler, Diamond \& Patton, Government Takings of Private Property at * 287 (cited in note 1) ("An overwhelming majority of citizens were astonished and dismayed by the decision" in Kelo).

${ }^{21}$ Eddie A. Perez, The Importance of Eminent Domain in Community Development Projects, 29 W New Eng L Rev 109, 109 (2006) (Perez is mayor of New London, Connecticut).

${ }^{22}$ Most eminent domain projects are taken by local governments. However, state governments also are intimately involved in many economic development projects in three ways. First, state funding and tax incentives often provide an important part 
Table 1. Correlation of Eminent Domain Reform with Regulatory Takings Measures

Post-Kelo Eminent Domain Reform

\begin{tabular}{lccc}
\cline { 2 - 3 } & & Did not adopt & Adopted \\
\hline $\begin{array}{l}\text { Regulatory Takings } \\
\text { Reform Legislation }\end{array}$ & Did not adopt & $18(36 \%)$ & $9(18 \%)$ \\
\cline { 2 - 3 } & Adopted & $11(22 \%)$ & $12(24 \%)$ \\
\hline
\end{tabular}

means of redistributing property from one set of owners to another, providing politicians with a valuable resource that can be exchanged for support. Professor Ilya Somin, for example, argues that economic development uses of eminent domain are "especially vulnerable" to rent-seeking because of their "nearly limitless" rationale, "low transparency," and the long time horizon necessary to discover the lack of public benefits. ${ }^{23}$ However much they might disagree on the motives for its use, both proponents and opponents agree that eminent domain is an effective means for redistributing property rights from one set of owners to another. As a result, it has positive value for legislators and will be abandoned only if the costs of doing so are offset by some benefit to the legislators.

Second, reforming eminent domain in the direction desired by the public is not difficult. Not only did multiple states adopt effective restrictions on eminent domain powers, but property rights activists, including the Institute for Justice's Castle Coalition, provided clear, straightforward model legislation that showed any legislator

of the total package. In Kelo, for example, Connecticut provided $\$ 15.35$ million in bond issues to support the New London plan. $125 \mathrm{~S} \mathrm{Ct}$ at 2659. Second, the local politicians involved work closely with their areas' state legislators in both politics and governance. See, for example, Richard C. Schragger, Can Strong Mayors Empower Weak Cities? On the Power of Local Executives in a Federal System, 115 Yale L J 2542, 2567 (2006) (program specific funding mechanisms used widely increases "state and federal politicians involvement in local affairs" but such funds "are necessary to achieve many city ends."). Third, there is considerable movement between state legislatures and local governments, with city council members and county commissioners frequently shifting to the legislature and legislators sometimes becoming mayors. Because of these close political and substantive ties between state legislators and local government officials, restrictions on one's feasible policy set affect the other as well. Thus if local officials are unable to use eminent domain to lower the cost of economic development projects, they will look to the state legislature for additional funding for the projects.

${ }^{23}$ Ilya Somin, Controlling the Grasping Hand: Economic Development Takings After Kelo, 15 S Ct Econ Rev 183, 201-03 (2007). 
interested exactly how to restrict the use of eminent domain. ${ }^{24}$ As a result, any state legislature that wished to do so could have passed an effective reform of eminent domain. The cost of passage was thus not drafting or considering legislation but the constraints imposed by the reforms on politicians' future uses of eminent domain.

Third, the costs of the constraints vary across states. Eminent domain provides a way of reducing the cost of economic development/rent-seeking (depending on one's perspective) ${ }^{25}$ Where there are more (fewer) other means of obtaining those benefits, a legislature will find accepting constraints on eminent domain less (more) costly. Where interest groups favoring the use of eminent domain to accomplish their goals are stronger (weaker), legislators will find it more (less) costly to impose restrictions that frustrate those uses. Likewise, stronger (weaker) groups opposing eminent domain use will increase (decrease) the cost in political support for legislators' votes against substantive reforms. Where the economic "pie" is expanding (shrinking), legislators will have more (fewer) other opportunities to generate rewards for their supporters. As a result, effective restrictions on eminent domain legislation add a constraint that restricts state and local governments in pursuit of the public interest and rentseeking alike that is more likely to be binding when the legislature is restricted in raising revenue through tax increases or the state's economy is not growing. And additional constraints will cost legislators more or less in terms of support when the balance between eminent domain's supporters and opponents is different.

Faced with a popular, straightforward measure to protect property rights, legislatures behaved differently. In this Article, I argue

${ }^{24}$ See, for example, Castle Coalition, Model Language for State Statutes Limiting Eminent Domain Abuse, online at http://www.castlecoalition.org/legislation/model/ state_statute.html.

${ }^{25}$ Economic development projects present a special case of eminent domain with respect to many problems. Where a government takes property for a classic public good (e.g. highway, park, school), there may be questions about the distribution of the benefits but the result of the taking is an asset theoretically available for use by any member of the public. In economic development cases, on the other hand, the property taken is generally either given directly to a private owner, often at a subsidized price, or used to primarily benefit a private property owner by creating support infrastructure for the private property owner's project. In these cases the potential for rent-seeking is magnified since the power of government is used to redistribute assets from one property owner to another, raising what Epstein aptly terms "the endemic problem of self-dealing." Epstein, 9 Green Bag $2 \mathrm{~d}$ at 128 (cited in note 7). This redistribution is perhaps partly the cause of the hostility to Kelo: "much of the reaction to the decision evinced hostility to the notion that local governments should ever condemn privately owned property and convey it to private developers in the name of economic development." Clayton P. Gillette, Kelo and the Local Political Process, 34 Hofstra L Rev 13, $13(2005)$. 
that the reason for the differences in state responses lie with these differences in the costs to state legislators of anti-Kelo restrictions on eminent domain powers. This Article uses the variation in state responses to Kelo to extend the explanation to the question of why some states responded with effective legislation while others did not. Using statistical analysis, I examine whether measures of states' political climate and of the other constraints on legislatures explain the variation in results. The empirical analysis supports the hypothesis that the different responses to Kelo are, at least in part, based on the different costs of accepting restrictions on a politically useful means of distributing resources to supporters.

The regressions provide three important results. First, spending and revenue restrictions make substantive reforms less likely, supporting the thesis that what matters in determining whether a substantive reform succeeds is the impact on legislators. Second, legislatures in growing states were more likely to adopt reforms than legislatures in stagnant and declining ones. This is consistent with the legislative cost explanation as well as with alternative theories discussed below. Third, the impact of politics is important. Greater Republican support in the legislature increased the chances of substantive reform. However, holding the degree of legislative control by Republicans constant, greater Republican political strength made substantive reforms less likely to pass. And measures of the ideological climate were insignificant. Taken as a whole, these results are consistent with a non-ideological explanation for the relative success of substantive reform.

\section{VARIATIONS IN STATE RESPONSES}

The "public outcry"26 over the Kelo decision produced legislative responses in many states remarkably quickly. ${ }^{27}$ These responses differed in a number of particulars, but I focus on three dimensions as most important in distinguishing a substantive from a symbolic effort: restrictions on the use of eminent domain for economic development, restrictions on the use of blight designations as a justifica-

\footnotetext{
${ }^{26}$ Epstein, 9 Green Bag 2d at 125 (cited in note 7).

${ }^{27}$ Professor Ely suggests that the rapid legislative response developed "because ordinary people realized for the first time that their homes and businesses were susceptible to aggressive exercise of eminent domain for economic development projects." Ely, 20 Prob \& Prop at 14 (cited in note 4). The timing of the responses varied in part because of the different meeting schedules, with some legislatures like Montana's not in session until months after the Kelo decision. Castle Coalition, 50 State Report Card at 30 (cited in note 14).
} 
tion for eminent domain, and adoption of constitutional, rather than merely statutory, restrictions on eminent domain. ${ }^{28}$

Much of the outrage over Kelo stemmed from New London's decision to sacrifice individuals' homes for a corporate development. As Justice O'Connor put it in her dissent, after Kelo "[n]othing is to prevent the State from replacing any Motel 6 with a Ritz-Carlton, any home with a shopping mall, or any farm with a factory. ${ }^{\prime 29}$ And the legal attack on the use of eminent domain in Kelo centered on the question of whether Susette Kelo's property was taken for a "public use" and whether the Constitutional text imposed a substantive requirement or not ${ }^{30}$ The Supreme Court's majority found that it did, in essence holding that the Constitutional requirement of a "public use" imposed few, if any, limits on the exercise of the power of eminent domain. On the other hand, eminent domain's use for more traditional school, road, bridge, and other infrastructure projects is far less controversial ${ }^{31}$ and seems less likely to be abused so long as compensation is required and paid. To eliminate the abuse without preventing the relatively noncontroversial "good" uses of eminent domain, state legislatures can limit the purposes for which eminent domain was used by adding language to their eminent domain stat-

${ }^{28}$ See Noel D. Campbell, R. Todd Jewell, and Edward J. Lopez, Pass a Law, Any Law, Fast! The States' (Somewhat) Symbolic Response to the Kelo Backlash, 44, "Attachment to Appendix" (October 2007) online at http://ssrn.com/abstract=1022385 (categorizing laws on 18 dimensions). Note that since I am focusing on legislative action, I count only reforms that pass through states' legislatures, not those that do not involve legislative votes such as amendments passed only through citizen-initiated initiatives. See note 44 .

${ }^{29} \mathrm{Kelo}, 125 \mathrm{~S} \mathrm{Ct}$ at 2676 (O'Connor, J., dissenting).

${ }^{30}$ Id at 2658 ("The question presented is whether the city's proposed disposition of this property qualifies as a "public use" within the meaning of the Takings Clause of the Fifth Amendment to the Constitution.") Scholars as diverse as Professor Merrill and Professor Adler argue that the "public use" language is not a substantive bar to economic development takings. See Merrill, 20 Prob \& Prop at 21-22 (cited in note 2) (suggesting the reading of "public use" most likely to reflect the framers' intent would have been as "descriptive of the power of eminent domain" $\left.\right|_{i}$ Jonathan H. Adler, Property Rights $\Theta$ Wrongs, National Review Online, June 29, 2005, online at http:// www.nationalreview.com/adler/adler200506290806.asp (expressing skepticism that the Constitution's text bars economic development takings).

${ }^{31}$ Nadler, Diamond and Patton, Government Takings of Private Property at *301 (cited in note 1) (noting public support for some forms of eminent domain and concluding that "beneath the vigorous public opposition to Kelo lay a more nuanced evaluation of government takings-a complex structure of public attitudes not easily gauged at an abstract level by simply measuring attitudes toward eminent domain in general"). There is also a history of eminent domain's use for things like grist mills that would certainly have been vulnerable to rent seeking. See Richard A. Epstein, Takings (1985) at $172-73$ (noting courts' misgivings about allowing takings in grist mill cases). 
utes or state constitutions that defines "public use" more restrictively by specifically excluding particular types of uses. For example, Florida restricted on transfers of property taken by eminent domain to private parties for ten years after the taking, banned blight takings, and imposed super-majority requirements on the legislature for exceptions, resulting in what the Castle Coalition termed "sweeping reforms [that produced]... some of the best protection in the nation." ${ }^{\prime 32}$

Once attention was focused on eminent domain abuse by Kelo, property rights activists argued that the use of a "blight" designation as a justification for taking property that by many Americans' standards was clearly not blighted in any usual sense of the word was another major problem, even though New London had not made use of a blight designation in Kelo. ${ }^{33}$ High profile cases like Lakewood, Ohio's blight designation of properties that lacked "two bathrooms, three bedrooms, an attached two car garage, central air-conditioning, or if the house or yard didn't meet minimum size requirements" ${ }^{\prime 34}$ caught the popular imagination as well. ${ }^{35}$ But the elasticity of the definition of "blight" that so outraged many people was a feature, not a bug, from the point of view of economic development officials in many state and local governments. In Lakewood, "the mayor maintained that [blight] is a term of art, or a statutory phrase generally invoked to describe whether or not the structures in the area 'meet today's standards,' and that the designation was necessary to enable the city to exercise its eminent domain powers. ${ }^{136}$ Restricting the use of blight designations as a justification for eminent domain would thus be a costly substantive restriction precisely because it would prevent eminent domain's use for projects like Lakewood's, projects that economic development officials and experts continued to support despite public outrage.

Finally, responses differ in whether they are statutory or consti-

${ }^{32}$ Castle Coalition, 50 State Report Card at 13 (cited in note 14).

${ }^{33} \mathrm{Kelo}, 125 \mathrm{~S} \mathrm{Ct}$ at 2660.

${ }^{34}$ Patricia E. Salkin and Lora A. Lucero, Community Redevelopment, Public Use, and Eminent Domain, 37 Urb Law 201, 219 (2005) (citing WCBS Newsradio 880, Eminent Domain: A 60 Minutes Special Report, Sept. 28, 2003, online at http://wcbs880 .com/rooney/sixtyminutes_story_271210317.html (last visited Mar. 3, 2005)..).

${ }^{35}$ The Lakewood dispute was covered on CBS' News program 60 Minutes and in the Washington Post. See Eminent Domain: Being Abused?, http://www.cbsnews.com/ stories/2003/09/26/60minutes/main575343.shtml; Blaine Harden, In Ohio, a Test for Eminent Domain, Wash Post at A03 (June 22, 2003).

${ }^{36}$ Salkin and Lucero, 37 Urb Law at 221 (cited in note 34). It is possible, of course, that a stringent blight requirement would act as a check on eminent domain abuse by allowing property owners to challenge a blight designation as arbitrary. The looseness of blight requirements mean that blight appears to have been more often used as an excuse than functioned as a constraint. 
tutional restrictions on the use of eminent domain. Constitutional changes are more durable than statutes, but also more expensive to procure. ${ }^{37} \mathrm{~A}$ constitutional amendment restricting eminent domain was thus a more costly response for the state legislature because it would be harder for the legislature to weaken it in the future. ${ }^{38}$

Legislators could choose between symbolic and substantive reforms because, despite the widespread popular distaste for Kelo itself which made adopting some form of "reform" a politically popular

${ }^{37}$ Profs. Donald Boudreaux and A.C. Pritchard's analysis of federal constitutional amendments predicts that interest groups are willing to incur the costs of obtaining constitutional provisions when the groups have high "maintenance costs" or expect opposition to their proposal to grow in the future. See Donald J. Boudreaux and A.C. Pritchard, Rewriting the Constitution: An Economic Analysis of the Constitutional Amendment Process, 62 Fordham L Rev 111, 118-21 (1993). "Maintenance costs" refer to the cost of maintaining the group's coalition to protect its gains. Interest groups with "[h]igh maintenance-costs ... will not anticipate being an effective political force in the future." As such, they "are likely to demand the greater durability provided by amendments." Id at 119. Temporary groups face higher maintenance costs than those already organized for other reasons. Boudreaux and Pritchard use the example of those who supported Prohibition (a high maintenance cost group, allied only for ideological reasons) and labor unions (low maintenance cost). The latter can anticipate being able to regularly lobby the legislature and so is willing to accept the cheaper alternative of legislation to accomplish its goals; the former has a serious free-rider problem in maintaining its coalition and so will prefer the more durable, but costly, constitutional amendment. Id at 119-20. The prospect of opposition arising in the future also enhances the desirability of an amendment. Where the losers from the policy are unknown today, but will be identified as a result of the policy going into effect, enshrining the policy in a constitution, which is difficult to change, rather than in a statute is more likely to be worthwhile. Id at 122 . The opposition to Kelo presents a situation with high maintenance costs; the outrage spawned by the decision was likely to dissipate over time as other events overtook it in the news, giving property rights groups an incentive to seek a constitutional change to lock in their gains.

${ }^{38} \mathrm{Utah}$ 's experience demonstrates this point. The legislature passed a stringent eminent domain reform before Kelo in 2005. In 2007, however, the legislature weakened the statute. Castle Coalition, 50 State Report Card at 48 (cited in note 14). A variant on this applies to the anti-Kelo legislation. The absence of a vigorous public political defense of Kelo (as opposed to a public "it is right on the law but wrong on the policy" position) suggests that the opposition to it is more likely to surface in back-channel ways. The political price paid by some eminent domain supporters in recent years (e.g. the 2004 Lakewood, Ohio mayoral election in which a high-profile supporter of eminent domain was defeated by an opponent who suggested he was at most ambivalent about the issue) is a further reason for those opposed to restricting eminent domain to work behind the scenes rather than in a public debate. Another distinction among responses lies in the source of the restriction. In most states, the response to Kelo came in the form of legislative proposals; in some, however, it came through citizen initiatives. (Of course, initiatives are available only in a minority of states, and the requirements to put an initiative on the ballot vary considerably from state to state, even among those which do allow citizen-initiated initiatives.) The presence of an initiative often spurs state legislatures to propose their own measures, to head off features of the initiative that they dislike. 
step, voters often did not distinguish symbolic from substantive reforms. It seems likely that the Kelo backlash did not mean a widespread public rejection of eminent domain in all circumstances. ${ }^{39}$ Clearly voters could make such distinctions, they simply did not. Professor Ilya Somin persuasively makes the case that the lack of effective legislative responses to Kelo is attributable in part to voters' rational ignorance about the substance of eminent domain reforms. ${ }^{40}$

${ }^{39}$ Nadler, Diamond and Patton argue that public opposition to eminent domain is more nuanced than the visceral reaction to Kelo indicated.

Beneath the vigorous public opposition to Kelo lay a more nuanced evaluation of government takings-a complex structure of public attitudes not easily gauged at an abstract level by simply measuring attitudes toward eminent domain in general. In particular, the level of support for the use of eminent domain appears to depend on, among other things, the nature of the property (homes, vacant land, etc.) and the proposed use of the property (a school, a shopping center, etc.). The complete rejection of eminent domain by $40 \%$ to $60 \%$ of respondents answering a general question probably reflects the salience of the Kelo facts and the outrage in response to its perceived unfairness rather than a wholesale rejection of the legitimacy of eminent domain.

Nadler, Diamond and Patton, Government Takings of Private Property at * 301 (cited in note 1 ).

${ }^{40}$ Ilya Somin, The Limits of Backlash: Assessing the Political Response to Kelo, 93 Minn L Rev 2100 (2009). Opponents of reforms have explained the reforms popularity through voter ignorance as well. See, for example, Patricia E. Salkin \& Amy Lavine, Measure 37 and a Spoonful of Kelo: A Recipe for Property Rights Activists at the Ballot Box, 38 Urb Law 1065, 1070 (2006) ("The overall result is that regulatory takings laws are presented to an electorate unequipped with the legal education or motivation to truly understand them amid a barrage of positive depictions. Often, this presentation is accomplished through highly financed media campaigns that drown out a disorganized opposition relying on complicated and emotionally unappealing policy arguments. Furthermore, the task of responding to property rights activists with opposing public policy arguments often falls on state and local governments, which are simply ill-equipped and lack the resources to do so."). Property owners are the classic large and diffuse group, likely to fall victim to rent-seeking because the costs of organizing them are high and the expected loss to each ex ante is relatively small. Property owners' interests in eminent domain reforms are twofold. First, if eminent domain powers are to be used, they want to maximize their own compensation, while minimizing the chance of over-compensation generally (which will increase the cost of projects that do not involve their own property). Second, they would like to minimize the chance of their own property being taken involuntarily. Based on the public reaction to Kelo it appears that when property owners pay attention to the issue, this latter interest dominates. Because these interests point in different directions, and because the chance of any particular individual's property being involuntarily taken is so small, the large, diffuse group of property owners generally plays the role that large, diffuse groups generally play in public choice analyses: they do not pay attention to eminent domain issues. The exception is when an event makes members of the general public pay attention to the issue. At this point, the issue is not whether the eminent domain question is resolved according to precedent but whether the political or legal system delivers the result the property owner wants. 
Somin's argument supports the assumption here that it is primarily the costs and benefits to legislatures that matters in determining the states' responses.

To convert the states' diverse responses into a variable capable of being statistically analyzed, I turned to a "report card" on eminent domain reform produced by the Castle Coalition, a "nationwide grassroots property rights activism project" of the Institute for Justice (which represented Ms. Kelo in the Kelo litigation) ${ }^{41}$ involved in organizing efforts to obtain eminent domain reforms. The Coalition graded states on a scale from $\mathrm{A}$ to $\mathrm{F}$ for their passage of eminent domain reform measures through June $2007 .{ }^{42}$ The Coalition's grades rested on a thorough analysis of each state's legislation, with heavy emphasis on the three criteria discussed above. I collapsed the twelve categories of grades (A to F, with intermediate + and - steps) into a dichotomous variable: ReformB ( 1 if the state received a B- or better, 0 otherwise).$^{43}$ Table 2 lists the states' Castle Coalition grades. Twenty-one of the states received a B-or better. Note that since my analysis focuses on legislatures' actions, I exclude from the statistical analyses those states where the reforms resulted solely from citizen-initiative and referenda. ${ }^{44}$

${ }^{4 l}$ Castle Coalition, About Us, http://www.castlecoalition.org/profile/index.html.

${ }^{42}$ Castle Coalition, 50 State Report Card (cited in note 14).

${ }^{43}$ An alternative approach would have been to use an ordered logit regression, capturing the additional information in the variations between the individual grades. This proved impossible, however, as the relatively small size of the dataset flimited to 50 states] meant that there were too many "empty" cells to conduct the regression. Another reason to avoid an ordered logit would be its imposition of the assumption of equal distance between the various grades, making the distinction between a B- and a $\mathrm{C}+$ the same as the distinction between a D- and an F. After reviewing the Castle Coalition narratives, I determined that this was not supported by the data.

${ }^{44}$ Four states have adopted eminent domain reforms through citizen-initiated methods: Arizona, Nevada, North Dakota, and Oregon and so pose a classification issue. (Some other states adopted reforms through multiple methods.) In addition, Utah had adopted a reform measure prior to Kelo and so poses a slightly different classification issue. In Arizona, the legislature had passed equivalent legislation that was subsequently vetoed by the governor. The initiative campaign essentially overrode the governor's veto and so I include Arizona in the analysis, since its legislature voted on and passed the legislation. Nevada's legislature adopted a statute implementing the initiative before its effective date. Admittedly the decision to pass such a measure was likely influenced by the election results, but the legislature's action still merits its inclusion in the analysis as it could easily have opted to simply allow the measure to go into effect on its own. Utah's legislature passed legislation addressing eminent domain issues (weakening its previous reforms) and so it merits inclusion. I opted to include Arizona, Nevada, and Utah in the analysis and to exclude North Dakota and Oregon. Excluding these states entirely did not change either the sign or relative magnitudes of the coefficients. 
Table 2. State Grades on Post-Kelo Reforms

\begin{tabular}{llllllll}
\hline State & Grade & \multicolumn{1}{c}{ State } & Grade & State & Grade & State & Grade \\
\hline Alabama & B+ & Indiana & B & Montana & D & Rhode Island & F \\
Alaska & D & Iowa & B- & Nebraska & D+ & S.C. & B+ \\
Arizona & B+ & Kansas & B & Nevada & B+ & S.D. & A \\
Arkansas & F & Kentucky & D+ & N.H. & B+ & Tennessee & D- \\
California & D- & Louisiana & B & N.J. & F & Texas & C- \\
Colorado & C & Maine & D+ & N.M. & A- & Utah & B \\
Connecticut & D & Maryland & D & N.Y. & F & Vermont & D- \\
Delaware & D- & Massachusetts & F & N.C. & C- & Virginia & B+ \\
Florida & A & Michigan & A- & N.D. & A & Washington & C- \\
Georgia & B+ & Minnesota & B- & Ohio & D & West Virginia & C- \\
Hawaii & F & Mississippi & F & Oklahoma & F & Wisconsin & C+ \\
Idaho & D+ & Missouri & D & Oregon & B+ & Wyoming & B \\
Illinois & D+ & & & Pennsylvania & B- & & \\
\hline
\end{tabular}

I constructed the dependent variable from the Castle Coalition's grades for two reasons. First, the grades were constructed by people intimately involved in the process of seeking reform legislation and so reflected a thorough understanding of the legislation. And, since the group intended its grades to be used in lobbying efforts, there were incentives for the group to accurately characterize the legislation. The narrative descriptions of each state's legislation explained why the score was assigned, making the scoring process transparent. Second, the grades combined multiple characteristics of the legislation into a single score, ${ }^{45}$ a crucial component in constructing an

${ }^{45}$ The Castle Coalition grades differed significantly from the scale constructed by Campbell, Jewell, and Lopez, Pass a Law, Any Law, Fast! at Table 1 (cited in note 28). Campell, Jewell, and Lopez examined eighteen characteristics of state laws, then summed the criteria, essentially assigning a positive value of 1 to each restriction and a negative value of 1 to each loophole. States with a net positive value received a score of 2 , states with a score of less than 0 received a score of 1 , and states with no statute (and so a score of 0 ) received a score of 0 . Id at ${ }^{*} 10$. The authors then used an ordered probit to examine the pattern of response.

There are two important sources of difference between the Campbell, Jewell, and Lopez score and the Castle Coalition grades. First, the Castle Coalition grades focus primarily on effective restrictions on blight and economic development uses of eminent domain and on whether the reform was put into the state constitution or not. Campbell, Jewell, and Lopez did not assign weight to the constitutional dimension at all and assigned equal values to each of the characteristics they included. As a result of the differences in methodology, twelve states received a score of 2 from Campbell, Jewell, and Lopez but a score of below B-from the Castle Coalition and three states received a score of 1 from Campbell, Jewell, and Lopez but a grade of B-or above from the Castle Coalition. Second, the Castle Coalition scored Arizona, Louisiana, Michi- 
empirical test dependent on the overall strength of reform efforts. ${ }^{46}$ Moreover, since I was concerned with the overall cost to legislatures of the reforms, a combined measure was more appropriate than a series of tests of individual variables measuring particular characteristics of the various state laws. ${ }^{47}$ Table 3 lists the descriptive statistics for ReformB, as well as for the other variables described below.

gan, Nevada, and South Carolina as having passed effective legislation and Campbell, Jewell, and Lopez did not, presumably because referenda were involved.

${ }^{46}$ So few states adopted all three elements fonly 5 received a grade of A-or better, essentially the set of all states adopting effective constitutional amendments addressing both blight and public use, that it was not possible to analyze only those receiving the highest score due to lack of sufficient variation.

${ }^{47}$ In three cases, the Castle Coalition grade differed from the effective/ineffective rating assigned by Professor Somin. See Somin, 93 Minn L Rev at 2115 (Table 4) (cited in note 40 ). The divergent categorization reflected different assessments of the reforms' provisions (Iowa, Idaho, and South Carolina). I opted to follow the Castle Coalition grades, largely as a matter of consistency. As a sensitivity check I recoded Idaho, Iowa, and South Carolina to match Somin's classification and found that this did not alter the signs or relative magnitudes of the results.

Somin rates Iowa's reform legislation as "ineffective," while the Castle Coalition gave the state a B+. Somin's critique of the Iowa statute is based on his concern its blight provisions could be read overly broadly by the courts. See Somin, 93 Minn L Rev at 2115 (Table 4) (cited in note 40 ). The Castle Coalition gave more weight to the improvements in the law, including a requirement of a property-by-property assessment, a restriction on taking of non-blighted properties unless $75 \%$ of the other parcels met the definition of blight, and a requirement that the government prove blight by clear and convincing evidence. Castle Coalition, 50 State Report Card at 19 /cited in note 14). I opted to follow the Castle Coalition grade for Iowa because Somin's criticism seemed too hypothetical to justify deviating from the consistent reliance on the Castle Coalition grades.

Somin rates Idaho's reform as "effective," while the Castle Coalition gave the state a D+. The lower Castle Coalition grade reflects a downgrading of the reform legislation for including a provision allowing eminent domain for "those public and private uses for which eminent domain is expressly provided in the constitution of the State of Idaho." Castle Coalition, 50 State Report Card at 16 (cited in note 14). Because the Idaho Constitution has only weak restrictions on eminent domain and the Idaho Supreme Court "has further weakened property rights by adopting an interpretation of public use that is not tied to-and therefore not restrained by-any traditional understanding," the Castle Coalition report card found this to leave "the door to eminent domain abuse ... wide open." Id.

Somin rated South Carolina's reforms as "ineffective," while the Castle Coalition awarded the state a B+. 50 State Report Card at 44. Somin was concerned that South Carolina's constitutional amendment left open too many loopholes through vague or undefined terms, concluding that "[a]t best, the amendment modestly increases the protection provided by current law." See Somin, 93 Minn L Rev at 2146 (cited in note 40 ). The Castle Coalition, on the other hand, gave South Carolina a B + , concluding that it provided "some of the strongest protection in the country from eminent domain abuse" because its restrictions on blight were effective at eliminating the ability to use blight designations. The difference ultimately came down to Somin's con- 
Table 3. Descriptive Statistics

\begin{tabular}{|c|c|c|c|}
\hline Variable & $\begin{array}{l}\text { All } \\
\text { States }\end{array}$ & $\begin{array}{l}48 \text { State } \\
\text { Sample }\end{array}$ & Description \\
\hline \multicolumn{4}{|c|}{ Dependent variable } \\
\hline ReformB & $\begin{array}{l}0.42 \\
(0.499)\end{array}$ & $\begin{array}{c}0.400 \\
(0.494)\end{array}$ & $\begin{array}{l}\text { Grade of B- or better on Castle Coalition } \\
\text { Report }\end{array}$ \\
\hline \multicolumn{4}{|c|}{ Independent variables } \\
\hline $\mathrm{RLegP}$ & $\begin{array}{c}50.2 \\
(15.1)\end{array}$ & $\begin{array}{c}49.8 \\
(15.1)\end{array}$ & $\begin{array}{l}\text { Proportion of legislative seats held by } \\
\text { Republicans (both houses combined) in } 2006\end{array}$ \\
\hline RGovP & $\begin{array}{l}49.9 \\
(8.45)\end{array}$ & $\begin{array}{l}50.0 \\
(7.91)\end{array}$ & $\begin{array}{l}\text { Percent of vote received by Republican } \\
\text { governor in last election }\end{array}$ \\
\hline Partial Birth & $\begin{array}{c}0.620 \\
(0.490)\end{array}$ & $\begin{array}{c}0.630 \\
(0.489)\end{array}$ & $\begin{array}{l}1 \text { if state restricts partial birth abortions, } \\
0 \text { otherwise }\end{array}$ \\
\hline ArtsPC & $\begin{array}{l}1.08 \\
(0.938)\end{array}$ & $\begin{array}{l}1.10 \\
(0.947)\end{array}$ & Per capita public funding for the arts \\
\hline EnvScore & $\begin{array}{l}45.6 \\
(34.2)\end{array}$ & $\begin{array}{r}44.73 \\
(34.7)\end{array}$ & $\begin{array}{l}\text { Combined score of state's U.S. senators in } \\
2005 \text { League of Conservation Voters scorecard }\end{array}$ \\
\hline Black & $\begin{array}{l}10.4 \\
(9.70)\end{array}$ & $\begin{array}{l}10.7 \\
(9.72)\end{array}$ & $\begin{array}{l}\text { Percent of state's population who are African- } \\
\text { American }\end{array}$ \\
\hline Gini & $\begin{array}{l}0.446 \\
(0.0213)\end{array}$ & $\begin{array}{l}0.447 \\
(0.0216)\end{array}$ & Gini coefficient for state \\
\hline TEL & $\begin{array}{l}0.58 \\
(0.499)\end{array}$ & $\begin{array}{l}0.58 \\
(0.498)\end{array}$ & $\begin{array}{l}1 \text { if state has tax and revenue limit, } 0 \\
\text { otherwise }\end{array}$ \\
\hline PopChg & $\begin{array}{c}20.0 \\
(17.2)\end{array}$ & $\begin{array}{c}20.2 \\
(17.3)\end{array}$ & Percent change in state population 1990-2005 \\
\hline
\end{tabular}

\section{THE COSTS OF REFORM}

It would be difficult to find other policies of local governments, or even state governments, which raised such passionate, uniform feelings. ${ }^{48}$

cern that the amendment itself did not define "public use" to not include economic development, although current case law in the state held that economic development was not a public use. See Somin, 93 Minn L Rev at 2145-46 (cited in note 40); Castle Coalition, 50 State Report Card, at 44 (cited in note 14). I opted for the Castle Coalition grade. Somin is surely correct that the South Carolina court could redefine public use to include economic development but the amendment provides at least as much protection as legislation defining public use narrowly which also could be changed by a future decision by a court or the legislature.

${ }^{48}$ Issues such as abortion provoke passionate views but not uniform ones. Nadler, Diamond and Patton note that the strength and uniformity of the public reaction to 
Because of the intensity and uniformity of popular feeling against Kelo-type uses of eminent domain, opposition to anti-Kelo reform tended not to be openly expressed. ${ }^{49}$ Although a few economic development officials and experts, ${ }^{50}$ the New York Times ${ }^{51}$ and Washington Post ${ }^{52}$ editorial pages, and some environmental groups defended the decision, ${ }^{53}$ public comment on the decision was overwhelmingly negative. ${ }^{54}$ The rewards for politicians of passing anti-Kelo reform legislation were thus immediate and straightforward. After passing an anti-Kelo reform politicians could report to their constituents that they had passed a piece of legislation with broad support protecting a core American value against grasping developers, tyrannical mayors, or other villains. If legislative success ever is a benefit to a politician's reelection bid, surely this would be such a case. ${ }^{55}$

In contrast, the costs to politicians of eminent domain reform were long term. Anti-Kelo reforms had important costs for legislators in six areas. First, by definition substantive reforms limited politicians' ability to use eminent domain in the future. These limits had variable costs across the states, however, since some states already constrained their legislatures' ability to spend to a greater degree than others did. Where spending would more difficult, restrictions on using the eminent domain power would be more costly.

Second, although popular support for anti-Kelo legislation was

Kelo are atypical of reactions to Supreme Court cases and find that Kelo is the most unpopular decision of the Rehnquist court. Nadler, Diamond and Patton, Government Takings of Private Property at *296 (cited in note 1)

${ }^{49}$ Defenses of the majority opinion are relatively rare. Most center on arguments that Kelo is a logical application of existing precedent and a reasonable interpretation of the Constitutional language and seek to shift the discussion away from the larger questions and focus on the opinion itself. For most of Kelo's defenders, the issue is not the wisdom of either New London's actions or even economic development takings more generally but whether the decision was correct as a matter of constitutional law.

${ }^{50}$ See, for example, Perez, 29 W New Eng L Rev 109 (cited in note 21).

${ }^{51}$ The Limits of Property Rights, NY Times (June 24, 2005) online at http://www .nytimes.com/2005/06/24/opinion/24fril.html. See Matt Welch, Why the New York Times $\nabla_{s}$ Eminent Domain, Reason (Oct. 2005) (reporting that the Times benefited from the use of eminent domain in an economic development project).

${ }^{52}$ Eminent Latitude, Wash Post, A30/June 24, 2005/online at http://www.washington post.com/wp-dyn/content/article/2005/06/23/AR2005062301698.html /opinion "correct" despite being "quite unjust").

${ }^{53}$ See Ilya Somin and Jonathan $\mathrm{H}$. Adler, The Green Costs of Kelo: Economic Development Takings and Environmental Protection, 84 Wash U L Rev 623, 626-27 (2006) (noting defense of Kelo by several environmental groups).

${ }^{54}$ See note 20.

${ }^{55}$ But see Somin, Limits, 93 Minn L Rev at 2156 (cited in note 40) (concluding from polling data that "most Americans are ignorant of the mere existence or lack thereof of post-Kelo reform in their states, and even fewer can tell whether the reform was effective or not.") 
bipartisan, interest groups supporting Republicans and Democrats were affected differently. Giving up eminent domain power was more costly for environmentalists ${ }^{56}$ and government employees and officials in declining urban areas, both groups that generally support the Democratic Party over the Republican Party. In addition, protecting property rights is a more central part of Republican ideology (even if not practice). ${ }^{57}$ Restrictions on eminent domain would thus be more costly to Democrats than to Republicans. ${ }^{58}$

Third, the competitiveness of the political environment in a state should affect the cost of reform in one of two ways. If legislators want to lure undecided voters, competition between them could yield more substantive reform as candidates and parties compete to prove they are more effective at protecting property rights. Alternatively, if Republican politicians are not motivated by their ideological position to promote limits on government when they control it (as the experience of the Republican Congress between 2000 and 2006 suggests is the case for federal level Republican politicians), the higher the level of general Republican support in the state (making their seats safer), the less likely Republican legislators will be to adopt substantive reforms.

Fourth, property rights issues are generally associated with conservative politicians rather than liberal ones. Since both the Democratic and Republican parties have internal differences over the degree to

${ }^{56}$ At least they appear to have thought so, even if they were incorrect on the merits. See Somin and Adler, 84 Wash U L Rev 623 (cited in note 53).

${ }^{57}$ At the very least, we rarely hear Democratic politicians making protection of property rights an important part of their campaign rhetoric. See Michael J. Gerhardt, Crisis and Constitutionalism, 63 Mont L Rev 277, 291 (2002) (noting that historically there is a pattern of Democrats (as the party purporting to represent populists and minorities)" mobilizing against Supreme Court "decisions protecting economic liberties and property rights, while Republicans (as the party purporting to defend majority and business interests) have tended to mobilize against decisions that favor minorities or reduced majoritarian power)." Then-House Minority Leader Nancy Pelosi certainly did not suffer any consequences from opposing efforts to withhold funds from projects using eminent domain by saying "When you withhold funds from enforcing a decision of the Supreme Court, you are in fact nullifying a decision of the Supreme Court," terming the efforts "a violation of separation of powers," and claiming that the Court's decision was "almost as if God has spoken." Mike Allen and Charles Babington, House Votes to Limit Cities' Use of Eminent Domain, Wash Post (July 1, 2005); David Lightman, Lawmakers Stand Up to Court, Hartford Courant at Al (July 1, 2005).

${ }^{58}$ There is some evidence that voting against one's constituents' economic interests can be costly for legislators. See William T. Bogart and Peter Van Doren, Do Legislators Vote Their Constituents' Wallets? (And How Would We Know If They Did?), 60 So Econ J 357, 372 (1993) (finding electoral penalty for legislators who voted against constituents' economic interests but concluding that this effect occurs only when "the economic effects of policy choices are salient"). 
which they are conservative, liberal, focused on economic or social issues, and so on, the political environment in the states can be measured by comparing legislative actions on non-property rights issues associated with liberal and conservative positions as well as through partisan divisions.

Fifth, states differ in their economic climates. Adopting eminent domain reforms in a growing economy is less costly for a legislature than doing so in a stagnant or declining one, since the legislators in a growing economy have greater opportunities for obtaining resources with which to pursue the public interest or rent-seek without the use of eminent domain. When the economy is shrinking or stagnant, however, redistributing existing property rights through eminent domain is more valuable as these alternatives are not as readily available. ${ }^{59}$

Finally, two interest groups have particular interests with respect to eminent domain that could affect the degree to which substantive reform was possible. African-Americans have a long history of being the victims of eminent domain and some, but not all, liberal African-American politicians have been at the forefront of reform efforts. Adopting substantive reforms should be of greater benefit for politicians representing a community attuned to the issue and so less likely to be rationally ignorant of the details of the legislation. Environmental pressure groups, on the other hand, favor the use of eminent domain to pursue their own agendas. Legislators in states with stronger environmental groups should therefore find adopting substantive reforms more costly. In this section I describe variables that operationalize these characteristics and which allow testing hypotheses derived from the brief descriptions above.

There are, of course, other explanations possible for the differences in states' responses to Kelo and the role of costs and benefits to legislators should not be seen as the only explanation possible. Even the highest estimate of the variation accounted for by the variables related to the legislative costs and benefits model is that they explain only $60 \%$ or so of the total variation. I cannot test some of the alternatives because of the lack of data and multiple interpretations are possible even where we have data consistent with the legislative costs and benefits approach. For example, Professor Somin has argued that Kelo-style takings do more economic harm than good, which provides an alternative direction for causation in examining the relationship between states' economic health and their responses

${ }^{59}$ I do not use the Castle Coalition's numbers on reported cases of eminent domain abuse, see Dana Berliner, Public Power, Private Gain (2003) because the data are simply those identifiable from news reports and the total for each state "represents only the tip of the iceberg." Id at 2. 
to Kelo. ${ }^{60}$ Alternatively, examining the frequency of Kelo-style takings across states would provide another measure of the demand for reform, but there is no consistent measure of such efforts by state and local governments. ${ }^{61}$

\section{A. Resource Constraints}

Legislators face binding resource constraints in accomplishing their goals, whether those goals are publicly spirited or rent-seeking. Fortyfour states require the governor to submit a balanced budget, forty require the legislature to pass a balanced budget, and thirty-eight forbid the state to carry over a deficit. ${ }^{62}$ (Only Vermont does not have at least one of these fiscal constraints.) In a resource-constrained environment, eminent domain offers government a discount on accomplishing its aims by reducing the transactions costs of projects even where full compensation is paid and, to the extent it permits undercompensation of property owners, a further discount by lowering the price of the projects. ${ }^{63}$ In some instances, eminent domain allows state and local governments to obtain resources from the federal government that they would not otherwise receive. ${ }^{64}$

There is little variation in the existence of a resource constraint through balanced budget requirements, although they certainly vary in their effectiveness, but there is considerable variation with respect to the presence of effective tax and expenditure limitations (TELs), which exist in only thirty-one states. ${ }^{65}$

TELs, particularly now that their spread has slowed, may have created an important and not easily reversible divide in the American federal system: between the states that have strong TELs and those that do not, a divide that may eventually produce large differences in spending and revenue priorities across the states. ${ }^{66}$

${ }^{60}$ See Ilya Somin, The Case Against Economic Development Takings, 1 NYUIL \& Lib 949 (2005).

${ }^{61}$ See note 121 and associated text.

${ }^{62}$ Ronald K. Snell, State Balanced Budged Requirements: Provisions and Practice Table 1 (2004), online at http://www.ncsl.org/programs/fiscal/balbuda.htm\#t1.

${ }^{63}$ If it was not cheaper to use eminent domain in some circumstances, people wouldn't use it.

${ }^{64}$ See, example, William A. Fischel, Before Kelo, Regulation 32, 34 (Winter 20052006) online at http://www.cato.org/pubs/regulation/regv28n4/v28n4-1.pdf /noting that $50 \%$ or more of the Poletown project was paid by sources other than Detroit).

${ }^{65}$ Subo Bae and Thomas Gais, The Effects of State-Level Tax and Expenditure Limitations on Revenues and Expenditures 5-6 (Rockefeller Institute, May 21, 2007) online at http://www.rockinst.org/WorkArea/showcontent.aspx?id=11804

${ }^{66}$ Bae and Gais, The Effects of State-Level Tax at 7 (cited in note 65). 
These limitations constrain state spending ${ }^{67}$ and alter local government expenditure patterns. ${ }^{68} \mathrm{~A}$ legislature operating under an effective TEL thus faces a constraint on its activities ${ }^{69}$ that would make adopting an effective eminent domain reform more costly than it would be for a legislature not operating under an effective TEL. Using data from the Rockefeller Institute's compilation of TELs, ${ }^{70} \mathrm{I}$ created a dummy variable equal to 1 if a state had an effective TEL and 0 otherwise. This yields:

Hypothesis 1: All else equal, a legislature in a state with an effective TEL will find substantive reform more costly and so be less likely to adopt a substantive eminent domain reform.

\section{B. Partisan Politics}

Many divisive issues in American politics, such as abortion and Social Security privatization, involve matters that touch on voters' deep moral concerns and/or affect vast resources such as the Social Security trust fund. They also generate significant levels of intensity

\footnotetext{
${ }^{67}$ See, example, Barry W. Poulson, Tax and Spending Limits: Theory, Analysis, and Policy, Independence Institute Issue Backgrounder IB-2004-E 1 (2004) online at http://www.i2i.org/articles/2004_E.pdf ("recent empirical studies support the 'public choice' view that budget institutions significantly effect fiscal policy. TELs, as well as other budget rules, can significantly reduce state and local spending."); Bae and Gais, The Effects of State-Level Tax at 5-6 (cited in note 65) /"state-level TELs significantly reduce the overall level of state and local spending (when spending is adjusted for inflation and state population |."

${ }^{68}$ See, example, Daniel R. Mullins, Tax and Expenditure Limitations and Fiscal Response of Local Government: Asymmetric Intra-Local Fiscal Effects, Public Budgeting \& Finance 111 (2004) (examining impact of TELs on local governments); Bae and Gais, The Effects of State-Level Tax at 6 (cited in note 65).

${ }^{69}$ Proponents and opponents of TELs agree that they restrict the ability of state governments to engage in spending. For example, in the 2004 debate over a TEL in Wisconsin, a proponent argued that a TEL was needed because

$[t]$ he problem is this insatiable appetite to spend. One of the things I have learned over the years is we are all very adept at protecting our little piece of the status quo. So, when you say we need to "support the kind of spending we want" or "fund what we think is important"-I can tell you what the municipalities think is important, I can tell you what the road builders think is important, I certainly know what the teachers think is important, I know what my manufacturers think is important. What we get is grief because everybody gets more spending.
}

James S. Haney, Comments on Taxpayer Bill of Rights, 88 Marq L Rev 173, 174 (2004). An opponent, on the other hand, argued that the TEL was "to dramatically reduce the scope of government" and was "a surface manifestation of more disguised attacks on public education and all institutions of government." Jack Norman, Is There Really $A$ Property Tax Crisis! 88 Marq L Rev 161, 172, 162 (2004).

${ }^{70}$ Bae and Gais, The Effects of State-Level Tax (cited in note 65). 
on both sides of the issue and are closely tied to partisan divisions: Democrats tend to be pro-choice and anti-privatization, Republicans tend to be pro-life and pro-privatization. In contrast, Kelo provoked bipartisan expressions of outrage and supporters of the initial wave of anti-Kelo legislation came from both sides of the aisle in most states. ${ }^{71}$ Many commentators noted this strong bipartisan commitment to eminent domain reform. For example, Nadler, Diamond, and Patton's survey of public opinion polling data on Kelo concluded that "[p]ublic disapproval of Kelo is notable in its uniformity across traditional political cleavages. The percentage of Democrats, Republicans, and Independents who oppose the Kelo decision is nearly equal in every poll, hovering between $80-85 \% . "{ }^{\prime 72}$

However, bipartisan hostility to Kelo among voters is not the same as bipartisan support for effective reforms. Because of voters' rational ignorance about the details of the legislative reforms actually enacted, symbolic reforms could satisfy the immediate political demand for action on eminent domain reform. ${ }^{73}$ There are several reasons to theorize that partisan differences with respect to substantive eminent domain reform might exist. First, it fits the pattern of behavior at the federal level. In Congress, both the bipartisanship and reforming zeal on eminent domain dissipated after the initial rush to condemn the Court's decision. Seventy-nine congress-

${ }^{71}$ John M. Broder, States Curbing Right to Seize Private Homes, NY Times, Al (Feb. 21, 2006) ("'It's open season on eminent domain,' said Larry Morandi, a land-use specialist at the National Conference of State Legislatures. 'Bills are being pushed by Democrats and Republicans, liberals and conservatives, and they're passing by huge margins."

Similarly, at the federal level, post-Kelo support for restrictions on eminent domain spanned the partisan divide. John Shirey of the California Redevelopment Association, an eminent domain supporter, complained in an interview that

[t]he politics of the situation are remarkable, because we have seen people from both ends of the political spectrum coming together. We have, on one hand, Congressman Richard Pombo-who anybody would view as on the far right-partnering with Congresswoman Maxine Waters-who just about every political observer would say is on the far left-to co-sponsor legislation that would all but prohibit the use of eminent domain at the local level if a local government wants to continue receiving federal funds.

Kelo Backlash Ignores Benefits of Eminent Domain for Redevelopment, The Planning Report (Dec 2005) online at http://www.planningreport.com/tpr/?module=displaystory \&story_id $=1128$ \& format $=$ html..

${ }^{72}$ Nadler, Diamond and Patton, Government Takings of Private Property at *298 (cited in note 1 ).

${ }^{73}$ See Somin, Limits, 93 Minn L Rev at 2169 (cited in note 40) ("it is likely that, to the extent that interest group opposition was able to stymie effective post-Kelo reform and force the passage of merely cosmetic legislation, this result occurred only because most ordinary voters are unaware of what is happening. Political ignorance is the handmaiden of interest group power in the political process, at least in this field."). 
persons cosponsored a symbolic resolution "[e]xpressing the grave disapproval of the House of Representatives regarding the majority opinion of the Supreme Court in the case of Kelo et al. v. City of New London et al. that nullifies the protections afforded private property owners in the Takings Clause of the Fifth Amendment" which passed by a margin of 365 to 33 (with 18 members voting "present") on June 30,2005 , just six days after it was introduced and a mere seven days after the Kelo decision. ${ }^{74}$ But this overwhelming positive vote concealed some important differences. Of the seventy-nine cosponsors ${ }^{75}$ only one was a Democrat, thirty-two of the thirty-three negative votes were by Democrats, ${ }^{76}$ and overall just under $80 \%$ of Republicans in the House voted for the resolution while only slightly more than $71 \%$ of Democrats did so. ${ }^{77}$ The same pattern held for the more substantive H.R. 4128, the Private Property Rights Protection Act, ${ }^{78}$ which passed $376-38$ on November 3, 2005: Just nine of the ninety-eight cosponsors were Democrats and only two of the thirtyeight negative votes were Republicans. ${ }^{79}$ In the Senate, only two Democrats were among the thirty-two cosponsors to Texas Republican John Cornyn's 2005 substantive eminent domain legislation..$^{80}$ Finally, when Nevada Republican Sen. John Ensign introduced a similar measure in the 110th Congress in January 2007, no Democrats (and only three other Republicans) signed on as cosponsors (as of November 10, 2007|.81 The implication of these voting patterns is that openly opposing anti-Kelo measures, even purely symbolic ones like H. Res. 340, was less costly for Democrats than for Republicans.

Second, three of the four state governors who vetoed substantive anti-Kelo measures were Democrats. ${ }^{82}$ All three of the Democratic

${ }^{74}$ H. Res. 340, 109th Cong. 1st Sess.

${ }^{75}$ Note that the House website does not include the bill's sponsor in the total number of cosponsors. I use "cosponsor" in the ordinary meaning of the word and so do include the sponsor, making my total numbers of cosponsors one greater than the House's.

${ }^{76}$ Oddly, the lone Republican "no" vote, Rep. John Hostettler of Indiana, was a cosponsor.

${ }^{77}$ Vote data from US Congress Votes Database, online at http://projects. washington post.com/congress/109/house/1/votes/361/.

${ }^{78}$ See Somin, Limits, 93 Minn L Rev at 2149-51 (cited in note 40) (discussing the substantive provisions of this proposal).

${ }^{79} \mathrm{HR} 4178$, 109th Cong, 1st Sess.

${ }^{80}$ S.1313, 109th Cong, 1st Sess. The two Democrats were California's Barbara Boxer and Florida's Bill Nelson.

${ }^{81}$ S. 48110 th Cong, lst Sess.

${ }^{82}$ Arizona's Janet Napolitano, Iowa's Tom Vilsack, New Mexico's Bill Richardson, Texas' Rick Perry. Castle Coalition, 50 State Report Card at 7, 19, 35, 47 /cited in note 14). 
governors cited opposition to the reforms from local government officials as an important reason for their actions despite overwhelming support in their respective legislatures ${ }^{83}$ for the vetoed bills. ${ }^{84}$ Texas $^{\prime}$ Gov. Rick Perry had supported the bill there until an amendment requiring compensation for "diminished access" to property due to new road or other construction was added. ${ }^{85}$ Perry's opposition was

${ }^{83}$ Arizona's bill passed $45-7$ in the state house and $19-8$ in the state senate. (Arizona State Legislature, online at http://www.azleg.gov/FormatDocument.asp ?inDoc $=/$ legtext $/ 47 \mathrm{leg} / 2 \mathrm{r} / \mathrm{bill} / \mathrm{hb} 26750 . \mathrm{asp}$ ). Iowa's legislature had passed its reform bill by 43.6 in the lowa Senate and $89-5$ in the lowa House. Rob Poggenklass, Legislators Ponder Special Session after Governor Vetoes Eminent Domain Bill, West Branch Times (June 22, 2006) online at http://www.westbranchtimes.com/article .php?id=995. New Mexico's had passed its bill by 39-0 and 60-0 margins. NM State Legislature, online at http://legis.state.nm.us/lcs/_session.asp? chamber=H\&type=++ \& number $=746 \&$ Submit $=$ Search $\&$ year $=06$. Texas' passed by $125-11$ in the state house (Texas State Legislature, online at http://tlo2.tlc.state.tx.us/hjrnl/80r/pdf/80RDAY85FINAL.PDF\#page $=45$ ) and $29-1$ in the state senate (Texas State Legislature, online at http://tlo2.tlc.state.tx.us/sjrnl/80r/pdf/80RSJ05-22-F.PDF\#page=291).

${ }^{84}$ See Carrie Watters, Eminent-Domain Bill Vetoed; Too Restrictive, Governor Says, Ariz. Republic (Jun 7, 2006) online at http://www.azcentral.com/arizona republic/local/articles/0607eminentdomain $0607 . \mathrm{html}$ (quoting governor as saying "said the bill would have created "inappropriate impediments to communities looking to make their neighborhoods safe and productive. While I oppose the use of eminent domain power to benefit private economic interests, this bill goes too far in restricting a city's ability to deal with slums and gangs," she wrote. "It removes local control, sets up a needlessly complex bureaucratic process for redevelopment efforts and creates inappropriate impediments to communities looking to make their neighborhoods safe and productive."); Bill Richardson, Governor's Task Force Eyes Eminent Domain Abuse, Albuquerque Journal (June 24, 2006) online at http:// www.abqjournal.com/opinion/guest_columns/470895opinion06-24-06.htm ("I was forced to veto an eminent domain bill after the last legislative session at the urging of cities and towns including Rio Rancho, Alamogordo, Carlsbad, Elida, Elephant Butte, Truth or Consequences, Tijeras, Pecos and Los Lunas. That bill was hastily written, overly vague and unfortunately left several loopholes that would have hit rural communities particularly hard."); Rob Poggenklass, Legislators ponder special session after governor vetoes eminent domain bill, West Branch Times (June 22, 2006) online at http://www.westbranchtimes.com/article.php?id=995 ("Vilsack said that HF 2351 would put Iowa at an economic disadvantage with other states. He cited four projects in particular that could be held up by the new legislation-a plastics plant in Clinton, an ethanol plant in Dyersville, commercial property in Burlington and an airport in Pella" and noting that Chambers of Commerce in "many of lowa's larger cities" opposed the bill); Gov. Rick Perry, Veto Message for House Bill No. 2006 (June 15, 2007), online at http://www.governor.state.tx.us/divisions/press/bills/veto_ statements/message-hb2006 ("Virtually every major city, county and high-growth area of the state asked me to veto this legislation because of the prohibitively high costs for future road construction and safety improvements and new schools that would be caused by these amendments.")

${ }^{85}$ Van Darden, Texas Farm Bureau Vows to Fight Over Eminent Domain Laws, Waco Tribune (Dec. 2, 2007) online at http://www.wacotrib.com/news/content/news/ stories $/ 2007 / 12 / 02 / 12022007$ wacFarm.html? cxtype $=$ rss \& cxsvc $=7$ \&cxcat $=11$ [noting that Perry would sign a bill without that provision). 
thus to a single provision, and one that was relatively unimportant to the larger issue as it related primarily to the price paid to landowners when their land was taken for highway construction.

Third, open opposition to post-Kelo limits on eminent domain came almost entirely from three groups, at least two of which are traditionally associated with Democrats: environmental pressure groups ${ }^{86}$ local government officials from declining urban areas, ${ }^{87}$ and urban planners. As discussed below, all three groups oppose limitations on local governments' eminent domain powers because they view those restrictions as preventing their use of eminent domain to accomplish their goals. Because of the overwhelming popularity of eminent domain reforms, however, opposition appears to have largely taken place through discussions with legislators about modifications of bills rather than efforts to win contested votes on the floor. More members who might be sympathetic to the concerns of these interest groups would mean it was more likely that reform bills would shift towards the symbolic through the addition of amendments weakening their protections than that they would be defeated outright on the floor of the legislature.

Fourth, in recent years protection of property rights has featured prominently in Republican campaigns; it has been a lesser theme, at most, in Democratic campaigns. If we take the relative prominence of property rights protection as a signal of what politicians believe are issues that will assist their election or reelection, this suggests that Republican politicians are more likely than Democratic ones to be concerned with passing substantive reforms. For all these reasons, it seems likely that the more heavily Republican a state legislature was, the more likely it was to pass substantive reform. To measure Republican legislative strength, I used the proportion of Republican seats in all houses of the state legislature in $2005 .{ }^{88}$ This yields:

Hypothesis 2: All else equal, the higher percentage of Republicans in the state legislature, the more likely a state is to adopt substantive eminent domain reforms.

Control of the state legislature is not the only important measure of partisan politics. The competitiveness of the state's political environment is also important. The political science literature has

\footnotetext{
${ }^{86}$ Somin and Adler, 84 Wash U L Rev at 626 (cited in note 53) ("environmentalists have been notably absent among Kelo's critics.").

${ }^{87}$ See note 118 .

${ }^{88}$ Note that Nebraska has a unicameral legislature. In alternative specifications, not reported for space reasons, substitution of variables measuring the level of Republican control of a particular house did not generally affect the other results with respect to sign or significance. Substitution of a dummy variable for Republican majority control of the legislature also had little impact on the overall results.
} 
established the importance of the competitiveness of elections as an important component of a state's political environment. ${ }^{89}$ Several measures of political competitiveness have been proposed by political scientists: the folded and unfolded Ranney indices, ${ }^{90}$ a district-level measure of competitiveness devised by Holbrook and van Dunk, ${ }^{91}$ and a similar index (with both folded and unfolded versions) devised by Brown and Bruce. ${ }^{92}$ However, all the published versions of these measures rely on data from the 1980s and 1990s. Rather than one of these indices, I used the percentage won by the Republican candidate in the most recent gubernatorial election (either 2004 or 2006). I chose this measure of competitiveness over the alternative indices for three theoretical reasons and one practical one.

The first theoretical reason is that there is no consensus in the literature about which of the multiple political science indices represents the appropriate form for measuring competitiveness at the state level, with disagreement over a variety of issues..$^{93}$ There is thus

${ }^{89}$ Thomas M. Holbrook and Emily van Dunk, Electoral Competition in the American States, 87 Am Pol Sci Rev 955 (1993) (summarizing literature). Competitiveness has generally been associated with greater political liberalism based on two related assumptions: "First, elected officials in competitive areas will be highly responsive to constituency needs, due to the risk of electoral defeat. Second, due to higher overall levels of voter participation in competitive environments, lower socioeconomic class interests will constitute a greater share of the electorate in competitive states than in non-competitive states." Holbrook and van Dunk, 87 Am Pol Sci Rev at 955.

${ }^{90}$ The folded Ranney index is based on the proportion of seats won by Democrats in the state legislature, the Democratic vote in the last gubernatorial election, and the percentage of time the governorship and legislature are controlled by the Democratic party. The factors are averaged and an index constructed between 0 (complete Republican domination) to 1 (complete Democratic control). The index is then "folded" to create an index between 0.5 and 1 , with 0.5 a perfectly competitive political environment and $\mathrm{l}$ a single party-dominated environment. Holbrook and van Dunk, at 955-56.

${ }^{91}$ This measure combines the percentage of the popular vote won by the winning candidate in state legislative elections, the margin of victory, whether the seat is a "safe" seat (with a party receiving $55 \%$ or more), and whether the seat was contested or not. Holbrook and van Dunk 87 Am Pol Sci Rev at 956.

${ }^{92}$ Robert D. Brown and John M. Bruce, Political Parties in State and Nation: Party Advantage and Party Competition in a Federal Setting, 8 Party Politics 635 (2002). Brown and Bruce calculate their index based on the margin of victory in the state House, state Senate, governor, US House, US Senate, and presidential races in an eight year period. These individual scores are then aggregated to the state level. Id at 642-43.

${ }^{93}$ For example, the Ranney indices focus on outcomes ( partisan control of government), while the Holbrook and van Dunk and Brown and Bruce indices measure the margin of victory in electoral contests; the Holbrook and van Dunk index differs from the Brown and Bruce index in its inclusion of uncontested seats and exclusion of gubernatorial races. 
no reason to favor a particular form of index as a general matter. The second theoretical reason is that, for the purposes of this Article, the need is for a measure of state-level political competitiveness independent of the direction of partisan control of the legislature itself (which is measured by another variable). The Republican candidate's percentage of the gubernatorial vote provides a state-level measure of overall competitiveness of the environment in which individual legislators must run for reelection. This captures both the direction of the state's political leanings (which would not be captured by a folded index) and the overall competitiveness of the state political environment. ${ }^{94}$ In contrast, all three of the political science indices include measures of the degree of Republican success in legislative elections as well, which would introduce potential multicollinearity with the variable measuring the degree of Republican support in the two houses of the legislature.

This variable allows testing of two alternative hypotheses about the political environment. ${ }^{95}$ An unfolded variable based on levels of Republican support whose value would test whether, holding the level of Republican support in the state legislature constant, an increasing level of statewide-support for Republicans-making Republican seats "safer" - increased (a positive coefficient) or decreased (a negative coefficient) support for substantive reform. Increased support would be consistent with legislators following their constituents' interests (a public interest model), while decreased support would be consistent with legislators with "safer" seats being less inclined to adopt a reform which was costly to them (a public choice model). These yield:

${ }^{94}$ There are idiosyncratic elements to gubernatorial contests, of course. But the margin in the gubernatorial contest appears more likely to measure state trends than the margin in the 2004 Presidential contest or in other federal races. Since those are included in the Brown and Bruce index, that appears to dilute the measure of state competitiveness important here. Using a folded version of the same variable-i.e. the wining candidate's margin-offers a means of testing whether it is the closeness of state's partisan divide that matters or whether it is the partisan direction of the environment that matters.

${ }^{95} \mathrm{~A}$ directionless, folded variable would be negative and significant if states which are closely divided (as signified by smaller values) were more likely to adopt a substantive reform. This would occur if there was a group of voters both capable of distinguishing between symbolic and substantive reforms and motivated to vote based on property rights issues. In a closely divided state, both parties would presumably compete for this group's support by adopting substantive reforms. See, example, Andrew P. Morriss, The Politics of the Clean Air Act, in Political Environmentalism 263, 283-85 (Terry L. Anderson, ed, 2000) (describing how competition between Pres. Richard Nixon and Sen. Edmund Muskie (the favorite for the Democratic presidential nomination in 1972) led to a more intrusive Clean Air Act Amendments of 1970. 
Hypothesis 3a: Legislators in a state with a higher degree of general support for Republicans will find adoption of substantive eminent domain reform less costly and more rewarding.

Hypothesis 3b: Legislators in a state with a more competitive political environment will find adoption of substantive eminent domain reform less costly and more rewarding.

\section{Issue Politics}

American politics are often portrayed on a single dimension, liberalconservative scale. Although this understates the complexity of American politics (many social liberals are economic populists; some economic populists prefer conservative social policies, etc.), there are issues that disaggregate some of these strains in American politics in ways that can shed light on the eminent domain reform legislation. Whether a state has restrictions on partial birth abortion (31 states do $)^{96}$ is a proxy for social conservative strength; per capita public funding for the arts is a proxy for social liberal strength (the mean is $\$ 1.08$ but the minimum is $\$ 0.06$ and the maximum is $\$ 5.36)$. While public opinion polling found no divide between conservatives and liberal voters with respect to support for eminent domain reform and neither abortion or arts funding are issues related to property rights for most voters, these are reasonable proxies for social conservative and liberal strength in a state. Given the distinctions exemplified by the difference between Republicans in Rhode Island (e.g. Sen. Lincoln Chafee, who received a 41, the lowest score of any Republican, on the National Journal's conservative composite score) and South Carolina (e.g. Sen. Jim DeMint, who received a 92.5, the highest of any Republican), ${ }^{97}$ measures of conservative and liberal strength more completely characterize states' political environments than do simple measures of partisan strength. ${ }^{98}$ This yields:

${ }^{96}$ Abortion data are taken from Guttmacher Institute, State Policies in Brief (2007) online at http://www.guttmacher.org/statecenter/spibs/spib_OAL.pdf. Although the Institute is affiliated with Planned Parenthood, and so not neutral in the abortion debate, its factual materials are reliable. Note that states were coded as having such a ban even if it had been permanently enjoined since the relevant fact was that the ban had been passed, not whether or not it was in effect.

${ }^{97}$ The National Journal scores are available at http://nationaljournal.com/vote ratings/sen/cons.htm. South Carolina's other Republican senator, Lindsey Graham, received a 70.8 score, giving the state an average senatorial score of almost twice that of Rhode Island's lone Republican senator.

${ }^{98}$ I use national figures like Chafee and DeMint for expository purposes here because the equivalent state figures are less likely to be recognized by out-of-state readers. For a discussion of the political science literature's methods for characterizing state ideology see Marshall H. Medoff, The Political Implications of State Political Ideology: A Measure Tested, 56 Am J Econ \& Soc 145 (1997). 


\section{Hypothesis 4: More conservative states will be more likely to} adopt substantive reform; more liberal states less so.

The only large interest groups whose representatives publicly suggested sympathy for the Kelo majority's opinion are environmental pressure groups. ${ }^{99}$ This "green defense," likely a mistaken one on the merits, ${ }^{100}$ is tied to two perceived interests of environmental pressure groups. First, they want broad eminent domain powers available to lower the cost of projects they support, ranging from infrastructure such as mass transit (a more traditional subject for eminent domain) to redevelopment of brownfields. Second, environmental pressure groups appear to fear the use of the anti-Kelo backlash as a weapon against other policies they favor (land use controls, regulatory takings generally) and so sought to limit its impact. To capture the strength of a state's environmental interest group community, I used the combined scores of the state's U.S. Senators on the League of Conservation Voters' Environmental Scorecard. Since U.S. Senators run statewide, this provides a reasonable measure of the degree to which elected officials in the state find it worthwhile to curry favor with voters for whom environmental pressure groups' views are important. ${ }^{101}$ This yields:

\footnotetext{
${ }^{99}$ See Somin and Adler, 84 Wash U L Rev at 304-305 (cited in note 53). John Echeverria,
} the executive director of the Georgetown Environmental Law and Policy Institute has offered the most comprehensive green defense of Kelo. Echeverria, Testimony, online at http://www.law.georgetown.edu/gelpi/news/documents/NewYorkTestimonyNovem ber2005.pdf. He made two claims in support: First, Kelo was correctly decided and is actually a narrower reading of the eminent domain power than prior eminent domain cases; and second, eminent domain is "an essential government power" and is particular important in preventing hold outs from stopping projects that deter sprawl, including mass transit and brownfield development. Further, Echeverria has argued that the anti-Kelo popular response does not indicate a lessening of popular sympathy for regulatory takings in land use control, and in fact indicates broad public support for "strong community protections." Id. (This point is supported by Nadler, Diamond and Patton, Government Takings of Private Property at "22-23 (cited in note 1) (suggesting more thorough reading of poll results showed continued support for some eminent domain uses.) Even this defense is qualified, however, by support for additional procedural steps to "weed out" inappropriate uses of eminent domain and "modest" additional compensation for residential property owners and tenants, although both of these types of reforms could be applied to focus eminent domain efforts on projects environmental pressure groups prefer.

${ }^{100}$ See Somin and Adler, 84 Wash U L Rev at 666 (cited at note 53) ("Economic development takings pose a significant threat to environmental quality, while providing few if any environmental benefits.").

${ }^{101}$ There are issues concerning whether the LCV Scorecard is accurate. See, for example, National Center for Policy Analysis, League of Conservation Voters Makes Traditional Misleading Attack on Republicans, Promotes Democratic Party Candidates, (Oct. 30, 2002) online at http://www.nationalcenter.org/TSR103002.html. What matters for the purposes of this Article is not whether the scorecard accurately 
Hypothesis 5: States with stronger political support for measures approved of by environmental pressure groups will be less likely to adopt substantive reforms.

\section{Economic Development}

Eminent domain for economic development is not a phenomenon of governments in growing regions; it is primarily used in stagnant and declining cities like Detroit, Lakewood, Ohio and New London, Connecticut. ${ }^{102}$ As the majority in Kelo noted, the city of New London had an unemployment rate "nearly double" that of Connecticut and its population was at its lowest level since $1920 .{ }^{103}$ Lakewood, Ohio, a Cleveland suburb, "has fallen victim to many of the ailments that plagued Cleveland in previous decades, suffering from 'an outdated infrastructure, an aging housing stock, decreas[ed] commercial investment and an eroding tax base. ${ }^{\prime \prime 104}$ As the tax base declines in such cities their politicians are reduced to dividing a shrinking pie and eminent domain becomes more attractive to them as a means of doing so. ${ }^{105}$

This is true regardless of whether one takes a public interest or a public choice view of economic development projects. Eminent domain abuse can occur even as part of well-intentioned economic development efforts. Government officials may take property from individual owners and transfer it to a favored developer in hopes of sparking economic development (e.g. the Lakewood, Ohio plan and Detroit's Poletown). At best, such efforts benefit the majority at the expense of a minority ${ }_{i}{ }^{106}$ at worst, favored interests are rewarded at

measures important votes on the environment but whether it accurately measures fidelity to the agenda of environmental organizations likely to oppose eminent domain reforms. The criticisms do not detract from this function.

${ }^{102}$ See Dick M. Carpenter II and John K. Ross, Victimizing the Vulnerable: The Demographics of Eminent Domain Abuse (Institute for Justice, June 2007) (finding that eminent domain abuse occurs most often in areas with low income and minority residents).

${ }^{103} \mathrm{Kelo}, 125$ S Ct 2655, 2658.

${ }^{104}$ Salkin and Lucero, 37 Urb Law at 218 (cited at note 34) (quoting Don Iannone, Lakewood, Ohio: Struggle to Get Land for Development, Econ Dev Futures Web J, (Oct. 20, 2003), online at http://www.don-iannone.com/edfutures/2003_10_19_ ed-futures_archive.htmll.

${ }^{105}$ Of 258 American cities ranked by CityMayors, the population in forty declined by more than $2 \%$ from 2000 to 2006 , falling between $0.1 \%$ and $2 \%$ in another 25 . Twenty-four more grew by less than $1 \%$. In contrast, 65 American cities grew by $10 \%$ or more in that same period, 27 of which grew by more than $20 \%$ and 17 of which grew by more than $30 \%$. See CityMayors, The Fastest Growing American Cities, online at http://www.citymayors.com/statistics/us-cities-growth-2007.html.

${ }^{106}$ Since minority objects, it is being paid less than its subjective value for the property and so receiving less than full compensation. Third, the eminent domain 
the expense of both the majority /who derive no benefit from plans that fail but bear the costs of the compensation for the takings) and the dispossessed owners. In either case, the rewards for the economic development efforts accrue to the officials promoting the economic development scheme. They either reap the political benefit of a successful development (a public interest explanation) or benefit from transferring resources to favored interests (a public choice explanation).

The economic development projects that require eminent domain offer the chance to increase tax revenues /whether this potential is often fulfilled is a separate question. $\left.\right|^{107}$ In particular, declining regions adjacent to greenbelt development have difficulty competing for tax revenue-generating sources. For example, in defending a controversial eminent domain project (later defeated) in Lakewood, Ohio in 2003, Bruce Katz of the Center on Urban and Metropolitan Policy at the Brookings Institution called eminent domain "a critical tool for cities that are depopulated. It is a way for them to protect the interests of all the citizens in a community by ensuring that the future tax base is secure. ${ }^{\prime 108}$ Declining urban area politicians' interest lies in minimizing the constraints on their ability to use their eminent domain powers. Because these politicians have ready access to legislators, we should expect their opposition to high profile, popular legislation like the post-Kelo eminent domain reforms to be conducted through changes to the legislation rather than through overt opposition. This appears to have occurred in at least some cases. Pennsylvania's eminent domain reform banned its use for economic development and limited the definition of blight but exempted areas previously designated as blighted in Pittsburgh, Philadelphia, and Delaware County for seven years. ${ }^{109}$

As a result, the value of eminent domain powers to politicians should be less in economically growing regions than it would be in

process may result in under-compensation of property owners because the process fails to correctly value the property which is taken. There are a variety of reasons why under-compensation might systematically occur. Richard Epstein catalogues a range of "systematic and institutional biases" for under-compensation, including governments' ability to reduce property values in advance of takings through infrastructure decisions. Epstein, Original at 360 (cited in note 6).

${ }^{107}$ See, example, Somin, $15 \mathrm{~S}$ Ct Econ Rev at 194-201 (cited in note 23) (discussing problems with economic development arguments for takings).

${ }^{108}$ Blaine Harden, In Ohio, A Defense for Eminent Domain, Wash Post (June 25, 2003) online at http://www.libertymatters.org/newsservice/2003/faxback/06-25-03_2504_ Ohio.htm.

${ }^{109}$ See 26 Pa Cons Stat Ann $\S 203(b)(3),(4)$, (5) (exempting certain areas from stricter standards until 2012). See also Castle Coalition, 50 State Report Card at 42 (cited in 14) (discussing exemptions). 
economically declining areas. ${ }^{110}$ To distinguish growing from declining states, I calculated the percent change in population from 1990 to 2005. ${ }^{111}$ Politicians in states whose economies are growing should be more willing to yield eminent domain powers in substantive reforms because those powers have less value to them than eminent domain powers do in states with a declining economy. This yields:

Hypothesis 6: States whose economies and populations are growing will be more likely to adopt substantive eminent domain reforms than states whose economies and populations are stagnating or declining.

One important caveat bears mention here. As noted earlier, there is evidence that eminent domain is an ineffective tool for economic development. ${ }^{112}$ Causation between economic decline and reform may thus run in either or both directions: states may be more economically successful to the extent that they avoid Kelo-style takings and so growing states may be more likely to adopt substantive reforms and to avoid the takings in the first place because their state and local officials have figured this out. My data does not allow untangling these alternative (and to some extent, complementary) explanations.

\section{E. Oppressing Vulnerable Groups}

Although many of the high profile eminent domain cases involve governments taking the homes of middle class people like Suzette Kelo or the Lakewood, Ohio homeowners, the history of eminent domain's use is replete with instances in which it was used primarily against politically vulnerable groups. For example, there is evidence of this in the urban redevelopment schemes and interstate highway routing decisions in the 1950 s and $1960 \mathrm{~s}^{113}$ and Justice Thomas noted in his dissent in Kelo that because urban renewal projects in the 1950s and 1960s so often displaced nonwhite and low-income

\footnotetext{
${ }^{110}$ It would be convenient to have a consistent measure of eminent domain's use across states. Unfortunately, no such measure exists.

${ }^{111}$ I chose this period for two reasons. First, the period needed to be long enough to distinguish consistent growth from random noise. Second, it needed to be short enough to avoid having recent trends swamped by historical patterns that no longer were likely to be valid predictors. I experimented with a range of different periods and found no major changes in results.

${ }^{112}$ See Somin, 1 NYUJL \& Lib 949 (cited in note 60).

${ }^{113}$ Garnett, 105 Mich L Rev at 120 (cited in note 4) ("Takers may be least concerned with avoiding the subjective losses of those political outsiders, including racial minorities and the poor, who are not attached to cohesive communities.").
} 
neighborhoods urban removal became known as "Negro removal." 114 Minority communities' accurate perception that they are vulnerable to eminent domain abuse has led to some high-profile opposition to the practice by Rep. Maxine Waters (D. Cal.), ${ }^{115}$ one of the most liberal members of Congress ${ }^{116}$ and an African-American, and the filing of an amicus in support of the property owners by the NAACP in Kelo. ${ }^{117}$ On the other hand, as noted earlier, ten of the thirty-seven members of the Congressional Black Caucus who voted on the symbolic $\mathrm{H}$. Res. 340 voted against it, including such leading African-American politicians as Rep. Jesse L. Jackson, Jr., Rep. Alcee Hastings, and Rep. Stephanie Tubbs-Jones. And large African-American populations in declining urban areas means that larger African-American populations are correlated with politicians ${ }^{118}$ who would be likely to oppose substantive reforms as limits on their own powers. ${ }^{119}$

If the historical experience of "Negro removal" dominated in

${ }^{114}$ Kelo, 125 S Ct 2655, 2687 (Thomas dissenting) (quoting Pritchett, The "Public Menace" of Blight: Urban Renewal and the Private Uses of Eminent Domain, 21 Yale L \& Pol'y Rev 1, 47 (2003)).

${ }^{115}$ Although Rep. Waters was a vocal opponent of Kelo, she did not cosponsor or vote on H Res 340. However, she did cosponsor and vote for H R 4128.

${ }^{116}$ Rep. Waters, who National Review termed "the famously fire-breathing leftwing congresswoman from Los Angeles," (Rich Lowry, "Mad Max" Stands with the Right, Nat'l Rev Online, (Aug. 5, 2005), online at http://www.nationalreview.com/ lowry/lowry200508050737.asp), tied for 29th most liberal on the National Journal's 2006 composite score and tied for 20th on the social liberalism subscore, making her more liberal than $91.2 \%$ of Congress generally and more than $95 \%$ of Congress on social issues. National Review, 2007 Vote Ratings, online at http://nationaljournal .com/voteratings/house/lib.htm?ol=lib_social\&o2=desc\#vr.

${ }^{117}$ Brief of Amici Curiae National Association for the Advancement of Colored People, AARP, Hispanic Alliance of Atlantic County, Inc., Citizens in Action, Cramer Hill Resident Association, Inc., and the Southern Christian Leadership Conference in Support of Petitioners, Kelo v. City of New London, No 04-108 (filed Dec 3, 2004) (available on Westlaw at 2004 WL 2811057 . However, many prominent AfricanAmerican politicians opposed HR 340, including Reps. Jesse Jackson Jr., Stephanie Tubbs-Jones, and Alcee Hastings. The Congressional Black Caucus split 27-10 (with 2 members not voting and one voting "present") on H Res 340, a much closer split than the House as a whole or the Democratic minority. On H R 4198, a more substantive measure, 27 members of the $\mathrm{CBC}$ voted for it and six voted against it. Although CBC support for HR 4198 was greater, the proportion of $C B C$ members voting no was still higher than the proportion of Democrats ( 36 of 193 voting) or members generally ( 38 of 414 voting).

${ }^{118}$ The mayors of six of the ten cities experiencing the largest declines in population from 2000-2006 are African Americans, for example. At the time of this writing, New Orleans (1), Detroit (2), Cleveland (3), Dayton (6), Buffalo (7), and Birmingham (8) all have African-American mayors.

${ }^{119}$ See generally Johnnie Dee Swain, Jr., Black Mayors: Urban Decline and the Underclass, 24 J Black Stud 16 (1993)/discussing role of African American mayors in declining urban areas). 
the African American community, then states with larger AfricanAmerican populations to be more likely to adopt substantive reforms than those with smaller African-American populations because politicians representing those constituents would be more likely to seek to protect their constituents with real reforms. ${ }^{120}$

States vary a great deal in their use of eminent domain for economic development purposes and it would be ideal to have a variable that measured the differences across states. The only potential source of such data is the Castle Coalition's report, Public Power, Private Gain, which includes data by state on condemnations between 1998 and 2003. Unfortunately, the data has major gaps. As the report itself notes, only twenty-four states collect comprehensive eminent domain data and there are comparability issues with the data that is collected. $^{121}$

An alternative measure of vulnerability to eminent domain abuse is the state's Gini coefficient, the standard economic measure of inequality. A state with a higher Gini coefficient has a greater degree of income inequality, and so a segment of the population more politically vulnerable to having its property redistributed by political leaders. ${ }^{122}$ If eminent domain is particularly valuable where there is a vulnerable population, eminent domain powers would be more valuable in a more "target rich" environment and a higher Gini coefficient should make adopting reforms more costly. This yields:

Hypothesis 7: States with larger African American and economically vulnerable populations will be more likely to adopt substantive eminent domain reforms than states with smaller African American and economically vulnerable populations.

\section{RESULTS}

Using the variables described above, ${ }^{123}$ I tested the seven hypotheses set out in the previous section using logistic regression analysis.

${ }^{120}$ In short, the history of abuse targeting African Americans might have been sufficient to overcome those voters' rational ignorance. Because eminent domain's history of abuse seems to have been primarily used against African-Americans, rather than racial minorities generally, I focused on this sub-population. Although some Hispanic organizations joined in the anti-Kelo movement, no Hispanic politicians emerged as leaders of reform of the same degree of prominence as Rep. Waters.

${ }^{121}$ See Berliner, Public Power, Private Gain at 2, 8 (cited in note 59). See also Somin, Limits, 93 Minn L Rev at 2116 (cited in note 40) (discussing limitations on this data, although concluding it could be used for different purposes).

${ }^{122}$ The Gini coefficient is higher when there are more retired people, all else equal, which could mask an association with poverty. I also explored other measures of poverty, which were not significant.

${ }^{123}$ As a check on multicollinearity among the dependent variables described above, I examined bivariate correlation matrices for all the independent variables. Although 
The results are presented in Table 4 . Note that the coefficients in logit regressions lack the natural interpretation of the coefficients in ordinary least squares regressions. The table presents the coefficients, while the discussion of the results includes comparisons of the impact of changes in the relevant variables on the odds of a substantive reform being adopted. ${ }^{124}$

Interpreting these results allows the following evaluation of the hypotheses.

Hypothesis 1: All else equal, a legislature in a state with an effective TEL will find substantive reform more costly and so be less likely to adopt a substantive eminent domain reform.

The regression results strongly support this hypothesis. The coefficient on TEL was significant and negative in every specification and the presence of an effective TEL reduced the odds of a state adopting a substantive reform from 0.66 to between 0.026 to 0.054 , depending on the specification. These strong results also support the overall argument of this Article that the appropriate focus is on the interests of the politicians voting on the reforms.

Hypothesis 2: All else equal, the higher percentage of Republicans in the state legislature, the more likely a state is to adopt substantive eminent domain reforms.

The results also strongly support this hypothesis. As Republican legislative strength increases, adoption of substantive reforms become more likely. The coefficients were positive and significant at the $5 \%$ level or better in every specification but one. ${ }^{125}$ To double the

there is no firm rule regarding what level of correlation indicates potential problems, only two variable pairs exceeded the most conservative cutoff: the percentage of African-Americans and the Gini coefficient (a Pearson correlation coefficient of 0.543 ) and the percentage of Republicans in the legislature and the environmental voting score of the state's U.S. Senators $(-0.528)$. Both were well below the level of concern used in many studies and, since three of the four variables involved proved resolutely insignificant, it does not appear that multicollinearity is a problem. Gregory C. Sisk, Michael Heise, and Andrew P. Morriss, Charting the Influences on the ludicial Mind: An Empirical Study of Judicial Reasoning, 73 NYU L Rev 1377, 1432-33 n 233 (1998) (discussing issue in detail).

${ }^{124}$ The odds multiplier approach to interpreting logistic regression results is discussed in detail in Sisk, Heise, and Morriss, 73 NYU L Rev at 1457-58 n 291 (cited in 123). Briefly, one starts with the odds of an outcome (for example, in the case of the TEL coefficient, $0.395 / 0.604=0.655$ ), then calculates the odds multiplier of the logistic regression coefficient by taking the antilog of the coefficient (e.g. $\exp (-3.25)=$ 0.039 for specification (1) and the TEL coefficient), and then multiplying the result by the initial odds ratio to produce the new odds ratio $(0.656 * 0.039=0.0256)$.

${ }^{125}$ Even there the sign was correct and the coefficient only narrowly missed the $5 \%$ level (the significance level was 6.3\%). Given the small number of observations, and the large number of variables included in specification (3), this is unsurprising. 


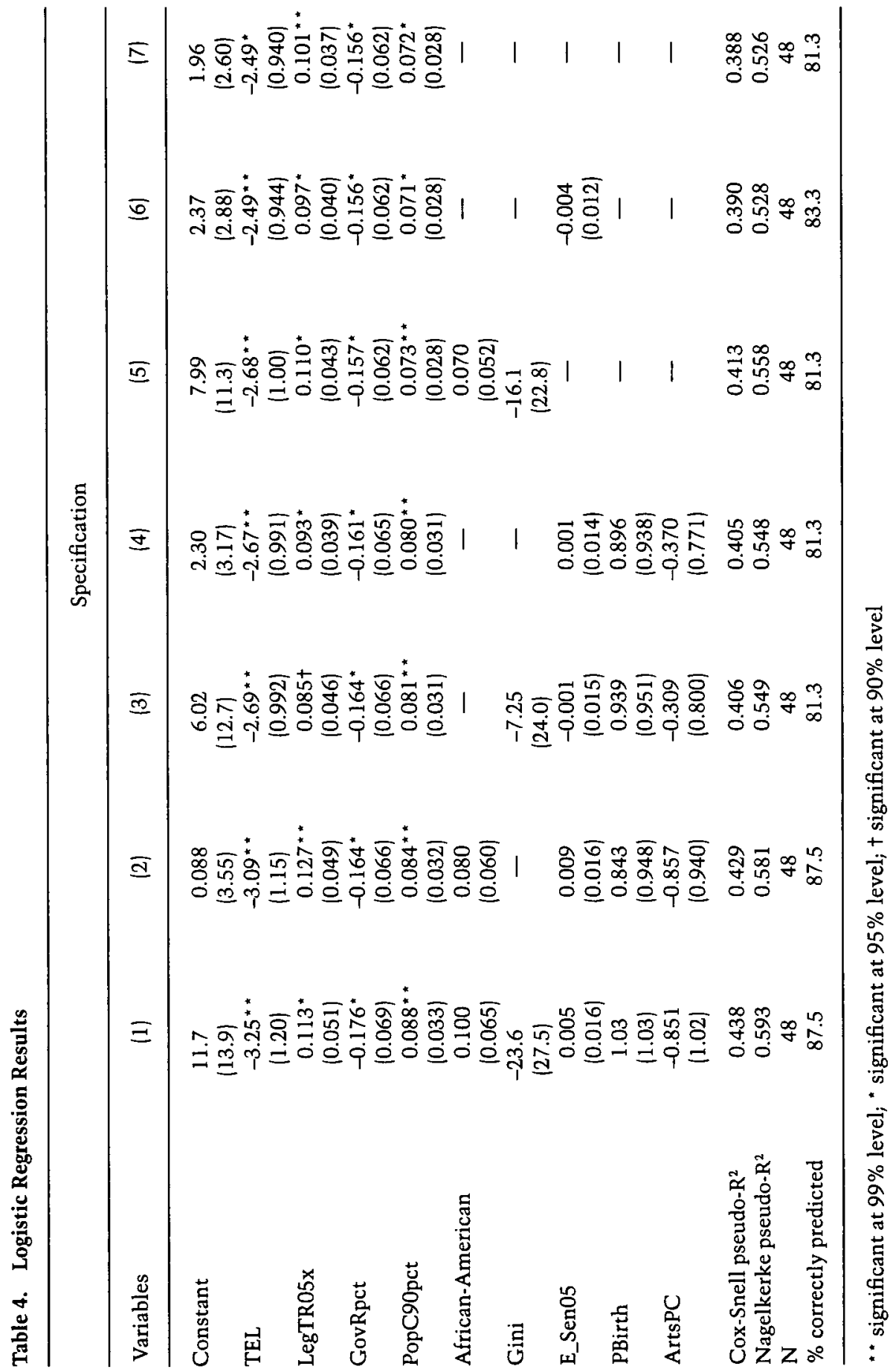


odds of a substantive reform's passage would require between an $8 \%$ and $14 \%$ increase in Republican support in the legislature, depending on the specification. ${ }^{126}$ Note that these results are not support for a greater degree of devotion to principle or public-mindedness among Republican legislators. Rather it is simply evidence that in this instance the net benefits to legislators of supporting substantive eminent domain reforms were greater for Republicans than for Democrats. These results do not distinguish among the potential explanations for why this was so. It thus could be that Republicans have a greater, principled attachment to property rights but it could also be that Republicans are less responsive to the needs of politicians in declining urban areas or other pro-eminent domain/economic development interest groups than Democrats purely for pragmatic or venal reasons.

Hypothesis 3a: Legislators in a state with a higher degree of general support for Republicans will find adoption of substantive eminent domain reform less costly and more rewarding.

Hypothesis 3b: Legislators in a state with a more competitive political environment will find adoption of substantive eminent domain reform less costly and more rewarding.

Republican strength in the most recent statewide gubernatorial race was significantly and negatively correlated with passage of a substantive reform, suggesting that the Republican commitment to property rights is less deep than party rhetoric might suggest when it comes to limiting their own power. A roughly $5 \%$ increase halved the odds ratio of adopting a substantive reform. While theory had provided two alternative hypotheses on the impact of states' political competitiveness, the results were consistent only with one (hypothesis $3 \mathrm{~b}$ ). If the obstacle to adopting substantive reforms over symbolic ones (or inaction) was the influence of the Democratic-leaning interest groups identified earlier within the legislature (persuading committee chairs to modify legislation to create exceptions, for example), then a measure of overall Republican strength, like the party's percentage in the last gubernatorial race would be significant and positive. If greater overall Republican strength led to a lessening of the likelihood of a substantive reform, this would suggest that greater security for Republican legislators would decrease their willingness

${ }^{126}$ On estimating increased odds for continuous variables, see David W. Hosmer and Stanley Lemeshow, Applied Logistic Regression 63-64 (2d ed 2000).

${ }^{127}$ Alternatively, if a folded variable measuring the winner's percentage in the most recent governor's race would be negative and significant this would be evidence that states with more competitive environments were more likely to enact substantive reforms, as politicians competed to win voter favor by doing so. Folded versions of this variable were insignificant when tried. 
to adopt a substantive reform that restricted their future actions. ${ }^{127}$ Taken together with the prior results on the degree of Republican support in the legislature, this is some evidence that it is not principle that motivates Republican legislators to be more supportive of substantive eminent domain reforms.

Hypothesis 4: More conservative states will be more likely to adopt substantive reforms; more liberal states less so.

Hypothesis 5: States with stronger political support for measures approved of by environmental pressure groups will be less likely to adopt substantive reforms.

The data provided no evidence that conservative, liberal, or green political cultures, at least as measured here, are associated with either greater or lesser likelihood of substantive reform. This result likely reflects two important features of the post-Kelo political landscape. First, outrage over the decision among voters was high among all political groups. There was no mass movement defending Kelo-style eminent domain, only efforts by affected interest group leaders to water down reforms. Given this uniform distaste for Kelo, it is not too surprising that variables measuring other political trends were uncorrelated with the outcome. Second, the differences between a substantive reform and a symbolic one lay in details not readily understandable by voters. Given rational ignorance, it is not surprising that the differences in outcomes were not associated with broader political trends. Indeed, the lack of significance for these variables tends to confirm that a model focused on the costs and benefits to legislators is the appropriate model.

The lack of a significant coefficient is not conclusive proof of the absence of an impact. However, the lack of significance for the measure of environmental group strength is noteworthy for two reasons. First, the variable was based on states' U.S. Senators' votes on the League of Conservation Voters Scorecard. That scorecard includes votes on precisely the sort of procedural votes and amendments that would be associated with weakening an eminent domain reform. If green pressure groups were behind the effective opposition to substantive eminent domain reform, this was a variable well-positioned to capture their behavior since it measured senators' willingness to vote on similar types of provisions in Congress. Given that it was resolutely insignificant in all specifications, this suggests that the effective opposition to eminent domain reform likely came from elsewhere.

Hypothesis 6: States whose economies and populations are growing will be more likely to adopt substantive eminent domain reforms than states whose economies and populations are stagnating or declining. 
States with growing economies, as measured by population growth, were much more likely to adopt substantive reforms. Growth one standard deviation above the mean increases the odds of adopting a substantive reform between 2.24 and 3 times, depending on the specification. This helps answer the puzzle noted by some commentators that states experiencing the most eminent domain abuse were not the most likely to adopt reforms and that states that had not experienced significant abuse did adopt reforms. ${ }^{128}$ In a public interest model, the cost of a reform in a growing economy was smaller than in a stagnating or declining one as eminent domain is not needed to accomplish economic development. In a public choice model, state and local governments have much less clumsy ways to redistribute wealth in a growing economy, ranging from tax abatements to state contracts. In either case, the results here suggest that growing states' legislators found substantive reforms less costly than legislators in declining and stagnating states.

As noted earlier, there is an alternative explanation consistent with this data. If economic development takings are simply rentseeking and not only do not produce economic development but inhibit economic growth /which is particularly likely if they are adopted more often in states that make other economic policy mistakes), causation may run in the other direction (or, perhaps, in both directions). Unfortunately, the data do not permit a test of which of these explanations is correct.

Hypothesis 7: States with larger African American and economically vulnerable populations will be more likely to adopt substantive eminent domain reforms than states with smaller African American and economically vulnerable populations.

Both the percentage of African Americans and the states' Gini coefficients proved resolutely insignificant, suggesting that the historical association of eminent domain with "Negro removal" programs was insufficient to raise the costs of opposing reforms for politicians sensitive to the concerns of African American or poorer communities within states. There are two plausible explanations for this pattern. First, despite the historical use of eminent domain in urban renewal projects that targeted minorities and the poor, eminent domain abuse today is news precisely because it has been expanded to be used against working and middle class property owners, as in Kelo and the

\footnotetext{
${ }^{128}$ See Somin, Limits, 93 Minn L Rev at 2105 (cited in note 40) (noting that several effective reforms "were enacted by states that had little or no history of condemning property for economic development. Only seven states that had previously engaged in significant numbers of economic development and blight condemnations have enacted post-Kelo legislative reforms with any real teeth.").
} 
Lakewood projects. As Justice $\mathrm{O}^{\prime}$ Connor noted in her dissent, what was so shocking to Americans was that "[n]othing is to prevent the State from replacing any Motel 6 with a Ritz-Carlton, any home with a shopping mall, or any farm with a factory." 129

Second, a key interest group involved in defending eminent domain powers are local government officials within declining urban areas. These officials are often African American politicians (e.g. former Detroit Mayor Coleman Young, a key backer of the infamous Poletown project in Detroit). ${ }^{130}$ A larger African American presence in a state means that there is also likely a larger percentage of African American politicians in the legislature with ties to these local officials. And the African-American political leadership was fragmented as shown by the divisions in the Congressional Black Caucus over the symbolic H.Res. 340. The lack of significance for these variables suggests that any political support for eminent domain reform based on the historical experience of the community is offset by the current interests of the politicians representing those communities.

\section{CONCLUSION}

The results of this analysis are consistent with several of the themes in the post-Kelo commentary critical of the decision. Many commentators on Kelo found the majority's high degree of deference to local governments, "supine deference" in Professor Ely's view, ${ }^{131}$ troublesome. As Professor Epstein summarized, Kelo "distorts the operation of public processes by giving state legislators, and the people who lobby them, too many degrees of freedom to engage in public mischief." 132 If the political process is dependent on the costs and benefits to legislators, as this analysis suggests it is with respect to eminent domain reform, it is unlikely that exercise of eminent domain powers will be checked by the political process. Given the strong correlation between economic growth and substantive eminent domain reform measures, it is especially unlikely that reforms will occur where they are most needed: in areas where eminent domain is most attractive to politicians. This is particularly true because of the combination of rational ignorance on the issue documented by Professor Somin and the high costs of maintaining the coalition seeking reform. ${ }^{133}$ If, as the response to Kelo suggests, the rules of eminent domain are

${ }^{129} 125 \mathrm{~S} \mathrm{Ct}$ at 2676 (O.Connor, J., dissenting).

${ }^{130}$ Fischel, Before Kelo, Regulation at 34 (cited in note 64) (Young's "eagerness" for the Poletown development "as surely a necessary condition" for the project).

${ }^{131}$ Ely, 20 Prob \& Prop at 14 (cited in note 4).

${ }^{132}$ Epstein, The Public Use at 126 (cited in note 7).

${ }^{133}$ See note 37. 
set through a political process unresponsive to voter interests due to rational ignorance and whose outcome is determined by legislators' own interests, even at a time of heightened scrutiny due to the "perfect storm"134 that followed the Kelo opinion, there is little hope that a process designed by state legislators will be sufficient to control eminent domain abuses in a great many cases. Effective reform requires finding constraints that do not depend on the responsiveness of politicians. This emphasizes the importance of constitutional reforms that effectively limit the types of eminent domain power most susceptible to abuse, the crucial role of citizen groups in seeking such reforms, and the courts in implementing them. ${ }^{135}$ Together with Professor Somin's finding that citizen-initiated referenda produced more substantive reforms, the results here counsel against reliance on legislatures for protection. Of course, reforms will not halt all economic development projects even if they are effective at stopping eminent domain abuse. But by putting such projects more fully "on budget," they will force legislatures to face opportunity costs and so be likely to prevent those projects that impose net social welfare losses. ${ }^{136}$

Professor Gillette offers one of the few defenses of Kelo on the merits. He argues that the majority correctly removes the courts from review where courts are unable to do better than the political process: "so much of the language of the decision implies that, given the process utilized in Kelo, the Court could not identify any apparent political process failure that courts could detect and correct better than the political process itself. ${ }^{137} \mathrm{His}$

claim is only that the capacity of the judiciary to make inquiries into the process, to reverse engineer the political decision to determine whether it was tainted or whether the same decision would have been reached on objective grounds, is minimal. Thus, perhaps the best that a court can do is to define the conditions under which the probability of abuse is minimal and defer to the political process when those criteria are satisfied. ${ }^{138}$

\footnotetext{
${ }^{134}$ Nadler, Diamond and Patton, Government Takings of Private Property at *305 (cited in note 1 ).

${ }^{135}$ See William M. Landes, and Richard A. Posner, The Independent /udiciary in an Interest Group Perspective, 18 J L \& Econ 875 (1975).

${ }^{136}$ See Andrew P. Morriss and Richard L. Stroup, Quartering Species: The "Living Constitution," the Third Amendment, and the Endangered Species Act, 30 Envtl L 769,807 (2000) (arguing that placing government programs like the Endangered Species Act "'on budget' would force" resource allocation choices "into the open" and "provide common measures of effectiveness ... with which to evaluate results.")

${ }^{137}$ Gillette, 34 Hofstra L Rev at 16 (cited in note 25 ).

${ }^{138}$ Id at 20.
} 
In Kelo, the existence of the larger development plan met this condition. ${ }^{139}$ But reliance on the political process is likely to be effective only where politicians face binding constraints on their exercise of the takings power. The Kelo majority's reliance on politics to check takings is thus likely at least partially misplaced.

Kelo's critics argued that courts can play an important role in evaluating public use claims and checking legislative abuses. As Professor Epstein noted, "there would be no reason to have any takings protection at all if governments routinely satisfied two key conditions. First, they only acted in the interests of the entire public every time they took land. And, second, they had superior knowledge of the anticipated consequences of their actions, so that on balance the use of the eminent domain power maximized social welfare. ${ }^{\prime 140}$ Since neither of these conditions hold universally, Epstein pointed to courts' ability to examine exercise of the eminent domain power, noting that "[t]here is no substitute for taking a careful look at the relevant deals" in assessing whether takings are legitimate exercises of public power or not. ${ }^{141}$ If legislatures are inadequate guarantors and the political process vulnerable, the best protection comes from constitutional provisions enforced by the courts.

Two conclusions are possible from the overall pattern of results found here. First, the division between states that adopted substantive eminent domain reforms and those that adopted either no reforms or purely symbolic reforms appears to be driven to a large extent by the cost of the reforms to politicians. The pattern of significance and sign on the various coefficients points in this direction with variables related to the cost of reform appearing reliably significant and with the correct signs to support this interpretation. Second, there is a partisan divide between Republicans and Democrats in the state legislatures in passing substantive eminent domain reform despite the bipartisan nature of immediate post-Kelo denunciations. This suggests that the interest groups opposed to eminent domain reform are most likely to have operated through back channels, seeking amendments and revisions to weaken reform proposals rather than directly opposing legislation. Since those interest groups (officials of declining metropolitan area governments and environmentalists) are predominantly linked to the Democratic party, greater Democratic control of the state legislature increased the chances of such changes. Further research is needed in developing better measures of political competitiveness and the presence of declining metropolitan areas.

\footnotetext{
${ }^{139}$ Id at 18-19.

${ }^{140}$ Epstein, 8 Green Bag 2d at 359 (cited in note 6).

${ }^{141}$ Epstein, 9 Green Bag 2d at 130 (cited in note 7).
} 